Historic, Archive Document

Do not assume content reflects current scientific knowledge, policies, or practices. 


\section{.}




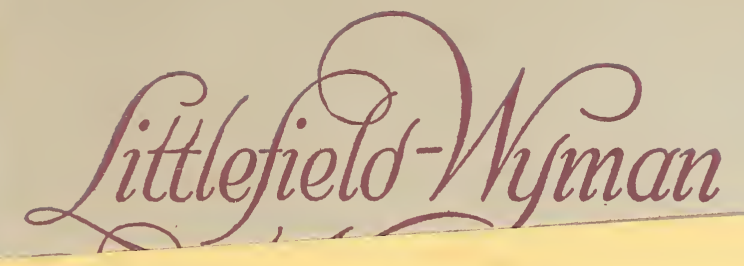

Nurserymen and Dealers are entitled to a

$$
\text { Discount of } 33 \frac{1}{3} \%
$$

from the prices in this list. Packing charges at cost.

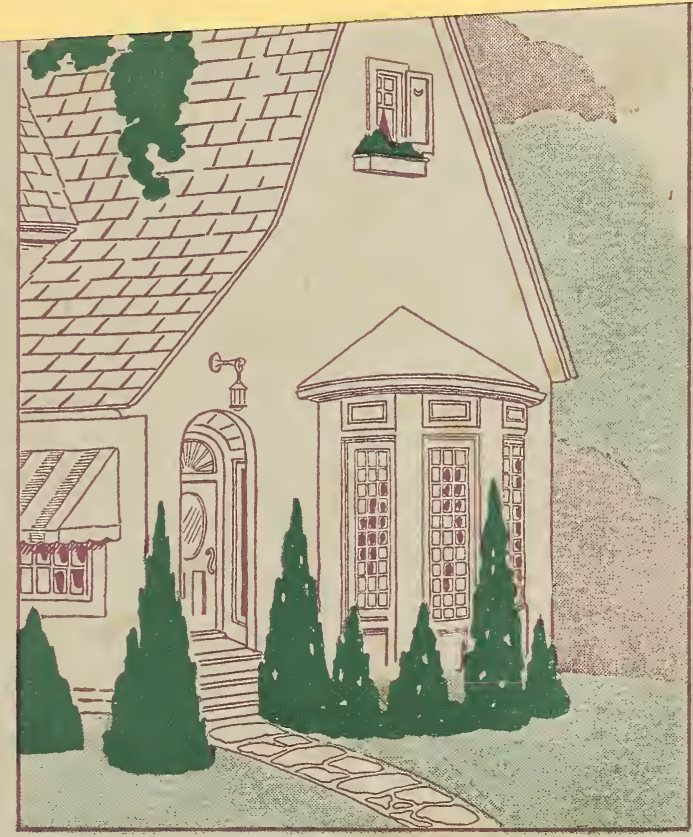

NORTH ABINGTON M A S S.

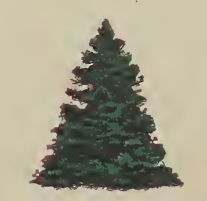

"TREES ARE FRIENDs" 


\section{LITTLEFIELD-WYMAN NURSERIES}

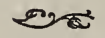

Office and Greenbouse

423 Adams Street North Abington, Mass.

Telephone Rockland 1200

\section{SHIPPING SHED}

Near Abington Passenger and Freight Station 227 Centre Avenue Abington, Mass.

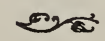

We are not open for business on Sundays

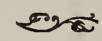

\section{INDEX}

\section{Page}

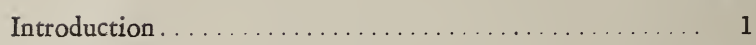

Deciduous Trees............................. 4

Deciduous Shrubs.......................... 8

Evergreen Trees............................. 17

Evergreen Shrubs............................ 24

Vines and Climbing Plants................... 26

Perennials.............................. 27

Roses.................................. 40

Fruits............................. 42

Bulbs............................... 44

Garden and Greenhouse Plants.................. 45

Miscellaneous............................ 48 


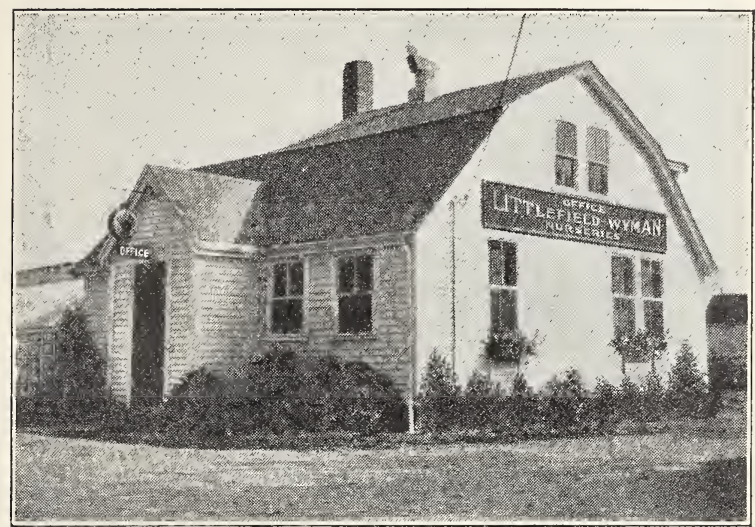

\section{OFFICE AND GREENHOUSES}

Our Office and Greenhouses are located at 423 Adams Street, North Abington, only a short distance from the North Abington Passenger Station and Electric Car line.

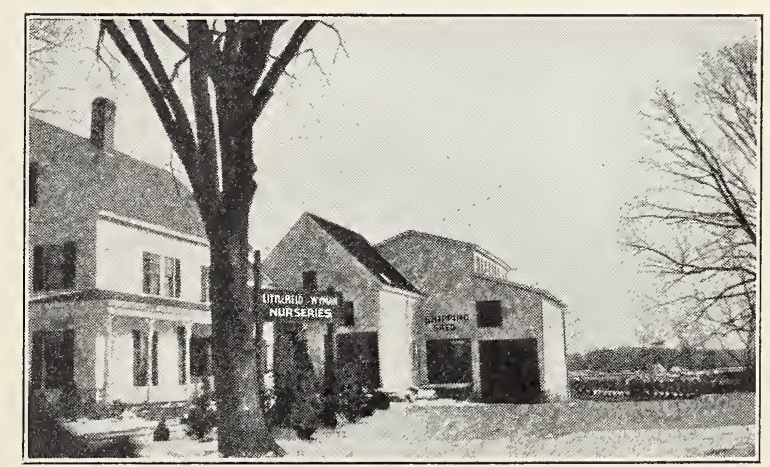

\section{SHIPPING SHED}

Our Shipping Shed is located at 227 Centre Avenue, Abington, very near the Abington Passenger and Freight Station, and on the Electric Car line. You will find someone in attendance every working day during the planting seasons. 


\section{Planting Seasons}

The SPRING PLANTING SEASON begins as soon as the frost is out of the ground and continues until early June. Evergreens and Perennials can be safely transplanted until the latter part of June.

The FALL PLANTING SEASON for Evergreens begins about the middle of August and continues through September. Deciduous Trees and Shrubs can be safely moved after we have had one or two frosts and continued until the ground is frozen. Perennials do best when moved during September and before the middle of October.

\section{Healtby Stock}

Growing dependable Nursery Stock which is healthy and free from disease is our job. Our plants are given plenty of room to develop in the Nursery row, are properly pruned and frequently transplanted. This careful attention gives us confidence that our product is equal to the best.

Poorly grown Nursery Stock is expensive at any price.

\section{Abbreviations}

Plants marked with an asterisk $\left(^{*}\right)$ denote varieties suitable for Rock Gardens.

Plants marked with a dagger $(\dagger)$ denote varieties that thrive at the Sea Shore.

Plants marked B. \& B. denote varieties dug with ball of earth and burlapped at no extra charge.

\section{Pruning}

Nearly all Nursery Stock presents a much better appearance if pruned and cared for at the proper time. We, therefore, offer you the services of our men who are trained in this important and particular profession.

\section{Conditions of Sale}

PRICES:- The prices annexed in this catalog are given net, f. o. b. Abington, and subject to change without notice. We make no charge for packing except on large deciduous and evergreen trees. Specimen plants selected by a customer, his representative, or by us will be charged for at an advanced price.

RATES:-The following rules apply only when the ten or hundred rates are given.

1 to 4 plants of one kind and size will be priced at the single rate.

5 to 24 plants of one kind and size will be priced at the ten rate.

25 or more plants of one kind and size will be priced at the hundred rate.

TERMS:-All orders from unknown customers must be accompanied by cash or its equivalent. All accounts are due in thirty days except by special arrangement. 
WE EXERCISE GREAT CARE TO HAVE ALL OF OUR PLANTS TRUE TO NAME. We give no warranty, expressed or implied, as to description, quality, productiveness or any other matter of any Nursery Stock, Seeds, Bulbs or Plants we sell.

CLAIMS:-No claims will be allowed unless made within ten days after receipt of stock.

\section{Transportation}

When we deliver stock to a transportation company our responsibility for its safety ceases. Your claims for damage should be made promptly to the agent of the transportation company at the point of delivery.

\section{Trucking}

We will make deliveries by truck within a radius of one hundred miles, and charge according to mileage and size of truck used. Stock so shipped will arrive quickly and in as perfect condition as when it leaves our Nursery. 


\section{Deciduous $T_{\text {rees }}$}

\begin{tabular}{|c|c|c|}
\hline & Each & Per 10 \\
\hline ACER dasycarpum & Silver Maple & \\
\hline 6 to $8 \mathrm{ft} .$. & $\ldots \$ 1.50$ & \\
\hline 8 to $10 \mathrm{ft}$. & 2.00 & \\
\hline 10 to $12 \mathrm{ft}$. & 3.00 & \\
\hline 12 to $14 \mathrm{ft} . .$. & $\ldots \quad 4.00$ & \\
\hline 14 to $16 \mathrm{ft} . .$. & $\ldots \quad 5.50$ & \\
\hline
\end{tabular}
d. wieri
Wier Maple
8 to $10 \mathrm{ft} \ldots \ldots \ldots \ldots \ldots . \quad 3.00$

\begin{tabular}{ccc} 
palmatum rubrum & \multicolumn{3}{c}{ Red Japanese Maple } \\
12 to 18 in.............. & 2.00 & 15.00 \\
18 to 24 in............. & 2.50 & 22.50 \\
2 to $21 / 2 \mathrm{ft} \ldots \ldots \ldots \ldots \ldots \ldots$ & 3.50 & 30.00 \\
$21 / 2$ to $3 \mathrm{ft} \ldots \ldots \ldots \ldots \ldots$ & 4.50 & \\
3 to $31 / 2 \mathrm{ft} \ldots \ldots \ldots \ldots \ldots \ldots$ & 5.50 &
\end{tabular}

\section{pennsylvanicum Striped Maple}

6 to $8 \mathrm{ft} \ldots \ldots \ldots \ldots \ldots .2 .50$

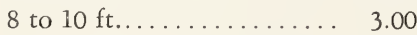

\section{tplatanoides Norway Maple}

$\begin{array}{llll}6 \text { to } 8 \mathrm{ft} \ldots \ldots \ldots \ldots \ldots \ldots & 2.50 & 22.50 & 200.00 \\ 8 \text { to } 10 \mathrm{ft} ., 1-11 / 4 \text { in. Cal.... } & 4.00 & 37.50 & 350.00\end{array}$

p. schwedleri Schwedler Maple

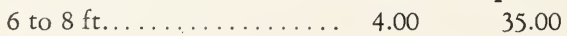

rubrum Red Maple

6 to $8 \mathrm{ft} \ldots \ldots \ldots \ldots \ldots \ldots . . .50$

8 to $10 \mathrm{ft} \ldots \ldots \ldots \ldots \ldots . \quad 3.00$

10 to $12 \mathrm{ft} \ldots \ldots \ldots \ldots \ldots .3 .50$

12 to $14 \mathrm{ft} \ldots \ldots \ldots \ldots \ldots .4 .50$

\section{saccharum Sugar Maple}

6 to $8 \mathrm{ft} \ldots \ldots \ldots \ldots \ldots \ldots .2 .50 \quad 22.50$

8 to $10 \mathrm{ft} .1-1 \frac{1}{4}$ in. Cal.... $3.50 \quad 33.00$

10 to $12 \mathrm{ft} .1 \frac{1}{4}-1 \frac{1}{2}$ in. Cal.. $\quad 5.00$

12 to $14 \mathrm{ft} .1 \frac{1}{2}-1 \frac{3}{4}$ in. Cal.. 6.00

14 to $16 \mathrm{ft} .2-2 \frac{1}{2}$ in. Cal... 8.50

16 to $18 \mathrm{ft} .21 / 2-3$ in. Cal... 10.00

Larger Specimens from $\$ 15$ to $\$ 100$ each

$\dagger$ ARALIA spinosa Devils-walkingstick

4 to $5 \mathrm{ft} \ldots \ldots \ldots \ldots \ldots . . . . . \ldots 0$

\section{BETULA alba \\ European White Birch}

6 to $8 \mathrm{ft}$................ 2.50

8 to $10 \mathrm{ft} \ldots \ldots \ldots \ldots . . . . . .3 .00$

10 to $12 \mathrm{ft} \ldots \ldots \ldots \ldots . . . .50$

$\dagger$ papyrifera Canoe Birch
4 to $5 \mathrm{ft}$.
1.50
5 to $6 \mathrm{ft} \ldots \ldots \ldots \ldots \ldots . . . . . .2 .00$
17.50
6 to $8 \mathrm{ft} \ldots \ldots \ldots \ldots . . . . .2 .50$
8 to $10 \mathrm{ft} \ldots \ldots \ldots \ldots . . . . . .60$

pendula gracilis Cutleaf Weeping Birch

4 to $5 \mathrm{ft} \ldots \ldots \ldots \ldots \ldots . \quad 3.00$

6 to $8 \mathrm{ft} \ldots \ldots \ldots \ldots \ldots . \quad 4.00$ 
CATALPA bignonioides nana (bungei)

\section{Each Per 10 Per 100}

3 yr. heads; 5-6 ft. Stems... $3.50 \quad 30.00$

$$
\text { speciosa Western Catalpa }
$$

8 to $10 \mathrm{ft} . \ldots \ldots \ldots \ldots . . . .50$

CERCIS canadensis American Redbud

2 to $3 \mathrm{ft} \ldots \ldots \ldots \ldots \ldots . . .75$

CHIONANTHUS virginica White Fringe

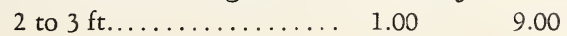

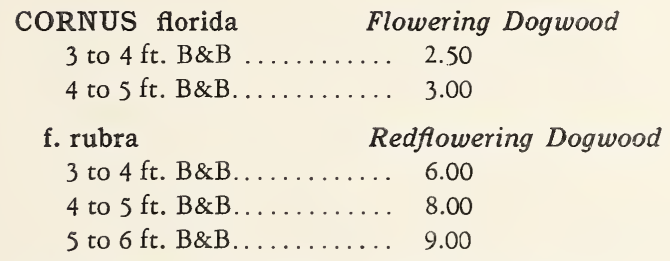

MAGNOLIA soulangeana Saucer Magnolia

2 to $3 \mathrm{ft} . \ldots \ldots \ldots \ldots \ldots . \ldots . . .60$

MALUS atrosanguinea Carmine $\mathrm{Crab}$

3 to $4 \mathrm{ft} \ldots \ldots \ldots \ldots \ldots \ldots . \ldots \ldots$

4 to $5 \mathrm{ft} . \ldots \ldots \ldots \ldots \ldots .2 .00$ 


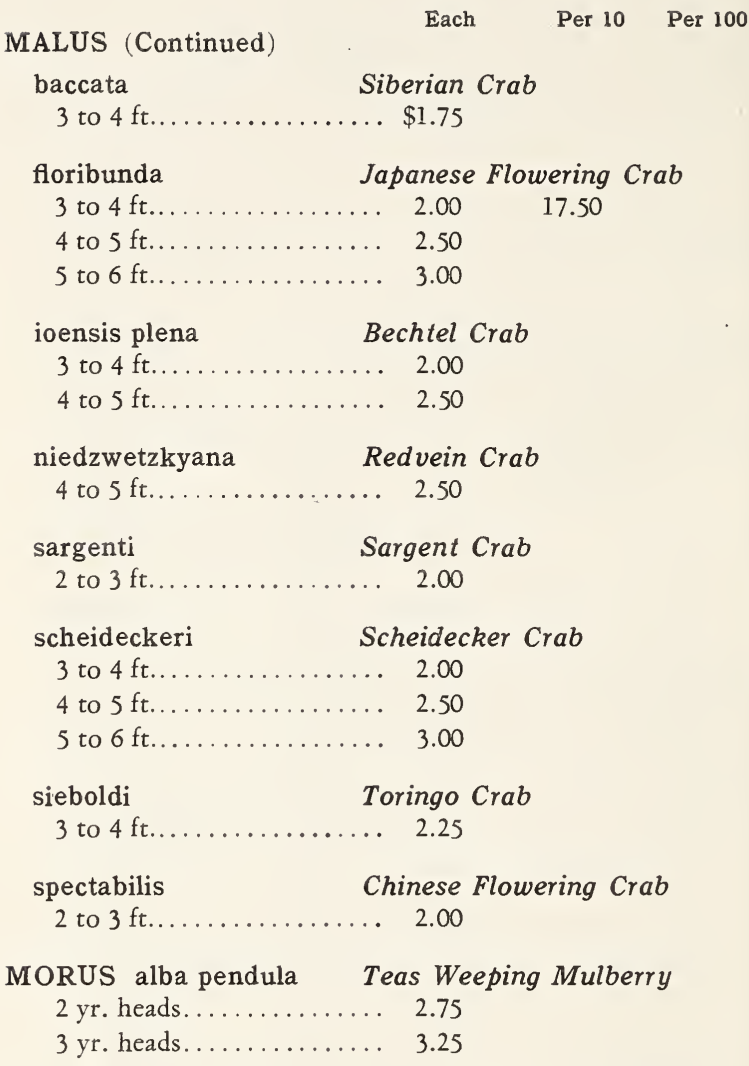

PLATANUS occidentalis American Planetree

8 to $10 \mathrm{ft} \ldots \ldots \ldots \ldots \ldots .2 .00$

10 to $12 \mathrm{ft} \ldots \ldots \ldots \ldots \ldots .2 .50$

$\nmid$ POPULUS balsamifera Balsam Poplar

10 to $12 \mathrm{ft} \ldots \ldots \ldots \ldots \ldots . . .1 .75$

12 to $14 \mathrm{ft} \ldots \ldots \ldots \ldots \ldots .2 .00$

14 to $16 \mathrm{ft} \ldots \ldots \ldots \ldots \ldots .2 .50$

16 to $18 \mathrm{ft} \ldots \ldots \ldots \ldots \ldots .3 .25$

candicans Balm of Gilead Poplar

10 to $12 \mathrm{ft} . \ldots \ldots \ldots \ldots . . . . .50$

12 to $14 \mathrm{ft} \ldots \ldots \ldots \ldots . . . . .200$

14 to $16 \mathrm{ft} \ldots \ldots \ldots \ldots \ldots .2 .50$

\begin{tabular}{lrr} 
teugenei & \multicolumn{3}{c}{ Carolina Poplar } \\
6 to $8 \mathrm{ft} \ldots \ldots \ldots \ldots \ldots \ldots$ & 1.00 & 9.00 \\
8 to $10 \mathrm{ft} \ldots \ldots \ldots \ldots \ldots \ldots$ & 1.25 & 11.00
\end{tabular}

nigra italica Lombardy Poplar

6 to $8 \mathrm{ft} . \ldots \ldots \ldots \ldots . . . . .1 .00 \quad 9.00$

8 to $10 \mathrm{ft} \ldots \ldots \ldots \ldots \ldots . . .25 \quad 1.25 \quad 11.00$

10 to $12 \mathrm{ft} \ldots \ldots \ldots \ldots . .1 .75 \quad 16.00$ 


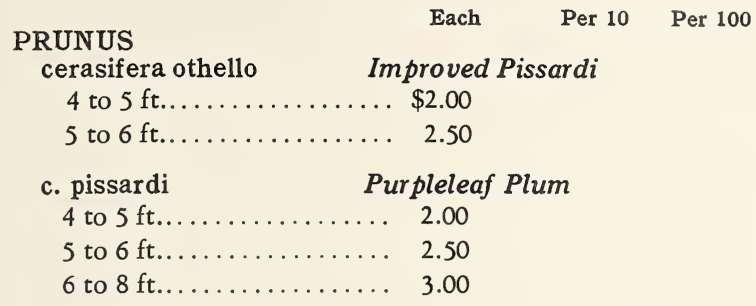

\section{Japanese Flowering Cherries}

Beni Higan-Single Blush Pink

3 to $4 \mathrm{ft} . \ldots \ldots \ldots \ldots \ldots . . . . . .60$

4 to $5 \mathrm{ft} . \ldots \ldots \ldots \ldots \ldots . . . . . . .60$

5 to $6 \mathrm{ft} \ldots \ldots \ldots \ldots \ldots \ldots .5 .50$

Kansan-Bright Pink

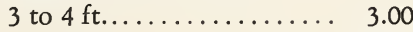

4 to $5 \mathrm{ft} \ldots \ldots \ldots \ldots \ldots \ldots . . .60$

5 to $6 \mathrm{ft} \ldots \ldots \ldots \ldots \ldots \ldots . \quad 5.50$

Kofugen-Buds Crimson-Blossoms Old Rose

3 to $4 \mathrm{ft} \ldots \ldots \ldots \ldots \ldots \ldots . . . . .60$

4 to $5 \mathrm{ft} \ldots \ldots \ldots \ldots \ldots .4 .00$

Naden-Lovely Double Pink

3 to $4 \mathrm{ft} \ldots \ldots \ldots \ldots \ldots . \quad 3.00$

4 to $5 \mathrm{ft} \ldots \ldots \ldots \ldots \ldots \ldots . . .60$

5 to $6 \mathrm{ft} \ldots \ldots \ldots \ldots \ldots \ldots .5 .50$

Yoshino-Buds Red, Single White Flowers

$\begin{array}{ll}4 \text { to } 5 \mathrm{ft} \ldots \ldots \ldots \ldots \ldots \ldots \ldots \ldots \ldots & 4.00 \\ 5 \text { to } 6 \mathrm{ft} . \ldots \ldots \ldots \ldots \ldots \ldots & 5.50 \\ 6 \text { to } 7 \mathrm{ft} \ldots \ldots \ldots \ldots \ldots \ldots & 8.00\end{array}$

fruticosa pendula Weeping Bush Cherry

$6 \mathrm{ft}$. Stem............ 5.00

QUERCUS palustris Pin Oak

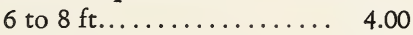

8 to $10 \mathrm{ft} \ldots \ldots \ldots \ldots \ldots .6 .50$

10 to $12 \mathrm{ft} \ldots \ldots \ldots \ldots . . .50$

Specimens 3-41/2 in. Cal. from $\$ 15$ to $\$ 60$ each

†SALIX blanda

Wisconsin Weeping Willow

6 to $8 \mathrm{ft}$

8 to $10 \mathrm{ft}$

2.00

10 to $12 \mathrm{ft} \ldots \ldots \ldots \ldots \ldots . \quad 3.00$

tpentandra

Laurel Willow

6 to $8 \mathrm{ft} . \ldots \ldots \ldots \ldots \ldots . . . .60$

8 to $10 \mathrm{ft} . \ldots \ldots \ldots \ldots \ldots . . .50$

10 to $12 \mathrm{ft} \ldots \ldots \ldots \ldots \ldots .2 .00$

fvitellina

Golden Willow

6 to $8 \mathrm{ft} . \ldots \ldots \ldots \ldots \ldots . . .25$

8 to $10 \mathrm{ft} . \ldots \ldots \ldots \ldots \ldots .2 .00$ 


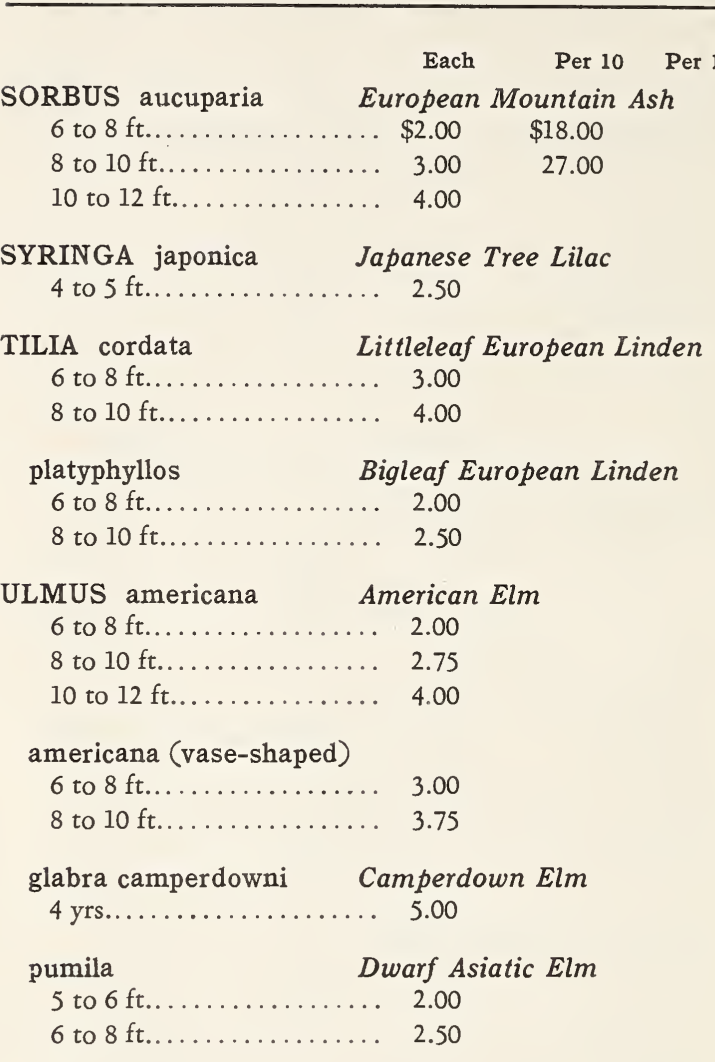

\section{Deciduous Sbrubs}

AMELANCHIER canadensis

Downy Shadblow

2 to $3 \mathrm{ft} . \ldots \ldots \ldots \ldots \ldots . . . . . .60$

AMORPHA fruticosa Indigobush

2 to $3 \mathrm{ft} . \ldots \ldots \ldots \ldots \ldots . .50$

†ARONIA arbutifolia Red Chokeberry

18 to 24 in............ .75

Azaleas will be balled and burlapped (B. \& B.) without extra charge.

AZALEA arborescens Sweet Azalea

12 to 15 in............ 1.50

15 to 18 in............ 2.25

18 to 24 in........... 3.00

calendulacea Flame Azalea

2 to $3 \mathrm{ft} . \ldots \ldots \ldots \ldots \ldots .4 .00 \quad 35.00$

canescens Gray Azalea

12 to 15 in............ $2.00 \quad 15.00$

15 to 18 in........... 2.50 
Each Per $10 \quad$ Per 100

\section{AZALEA (Continued)}

\section{kaempferi hybrids}

12 to 18 in........... \$8.00

Carmen-Carmine rose

Cleopatra-Light lilac rose

Fedora-Deep salmon rose

Louise-Light rose

Othello-Hinodegiri-brick-red

Zampa-Strawberry red

\begin{tabular}{|c|c|c|}
\hline mollis-Mixed Colors & \multicolumn{2}{|c|}{ Chinese Azalea } \\
\hline 12 to $15 \mathrm{in} . .$. & .. 3.00 & 27.00 \\
\hline 15 to 18 in. & 3.50 & 32.50 \\
\hline 18 to 24 in. & 4.50 & 42.00 \\
\hline 2 to $21 / 2 \mathrm{ft}$. & 6.00 & \\
\hline
\end{tabular}

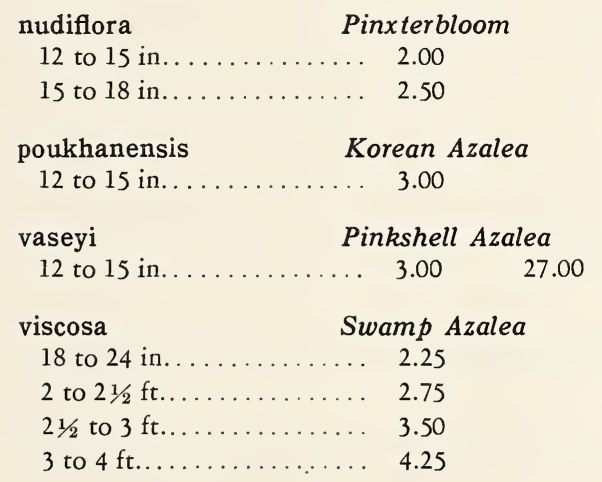

\begin{tabular}{|c|c|c|c|}
\hline †BERBERIS thunbergi & inese & erry & \\
\hline 12 to 15 in............. & .20 & 1.50 & 9.00 \\
\hline 15 to 18 in. . & .25 & 2.00 & 12.00 \\
\hline 18 to $24 \mathrm{in.} \mathrm{.}$ & .35 & 2.50 & 18.00 \\
\hline
\end{tabular}

\section{†thunbergi atropurpurea Red-leaved Japanese Barberry}

12 to 15 in............ $1.10 \quad 10.00$

\begin{tabular}{cccc} 
thunbergi minor & \multicolumn{4}{c}{ Box Barberry } \\
6 to 8 in $\ldots \ldots \ldots \ldots \ldots \ldots$ & .75 & 6.50 & 60.00 \\
15 to 18 in $\ldots \ldots \ldots \ldots \ldots \ldots$ & .90 & 7.50 &
\end{tabular}
tvulgaris
European Barberry

2 to $3 \mathrm{ft}$.

.60

\section{BUDDLEIA alternifolia}

2 yrs........... 3.00

davidi magnifica Oxeye Butterfybush

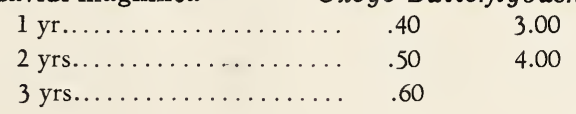




\section{Each Per 10 Per 100}

CALLICARPA purpurea Chinese Beautyberry

2 to $3 \mathrm{ft} \ldots \ldots \ldots \ldots \ldots \ldots 1.50$

CALYCANTHUS floridus Common Sweetshrub

18 to 24 in.............. 60

\begin{tabular}{|c|c|c|}
\hline †CLETHRA alnifolia & Summers & \\
\hline 2 to $3 \mathrm{ft} .$. & .75 & 6.50 \\
\hline 3 to $4 \mathrm{ft}$. & .90 & 8.00 \\
\hline
\end{tabular}

†CORNUS alba (siberica) Tatarian Dogwood

3 to $4 \mathrm{ft} \ldots \ldots \ldots \ldots \ldots . .60$

\begin{tabular}{|c|c|}
\hline $\begin{array}{l}\text { amomum } \\
5 \text { to } 6 \mathrm{ft} . .\end{array}$ & $\begin{array}{l}\text { Silky Dogwood } \\
\ldots \quad 1.00\end{array}$ \\
\hline †paniculata & Gray Dogwood \\
\hline 2 to $3 \mathrm{ft} .$. & .. .75 \\
\hline 3 to $4 \mathrm{ft} .$. & . 1.00 \\
\hline sanguinea & Bloodtwig Dogwood \\
\hline 3 to $4 \mathrm{ft} .$. & .. $\quad .75$ \\
\hline stolonifera & Red-osier Dogwood \\
\hline 2 to $3 \mathrm{ft} .$. & $\begin{array}{ll}\ldots .50\end{array}$ \\
\hline 3 to $4 \mathrm{ft} .$. & $\begin{array}{ll}\ldots .60\end{array}$ \\
\hline
\end{tabular}

stolonifera flaviramea Goldentwig Dogwood

18 to 24 in............ .50

†CYDONIA japonica Flowering Quince

18 to 24 in........... . 75

DAPHNE mezereum February Daphne

12 to 15 in........... $1.00 \quad 9.00$

DEUTZIA gracilis Slender Deutzia

15 to 18 in............ $.75 \quad 6.50$

18 to 24 in........... $.90 \quad 8.00$

lemoinei Lemoine Deutzia

2 to $3 \mathrm{ft} . . . \ldots \ldots \ldots \ldots \ldots . .75$

scabra crenata Double Pink Deutzia

3 to $4 \mathrm{ft} \ldots \ldots \ldots \ldots \ldots .60$

s. eximia

2 to $3 \mathrm{ft} \ldots \ldots \ldots \ldots \ldots \ldots$

s. Pride of Rochester Pride of Rochester 18 to 24 in............ .40

2 to $3 \mathrm{ft} \ldots \ldots \ldots \ldots \ldots \ldots . .50 \quad 4.00$

3 to $4 \mathrm{ft} \ldots \ldots \ldots \ldots \ldots \ldots . \quad .60 \quad 5.00$

5 to $6 \mathrm{ft} \ldots \ldots \ldots \ldots \ldots \ldots .90$ 


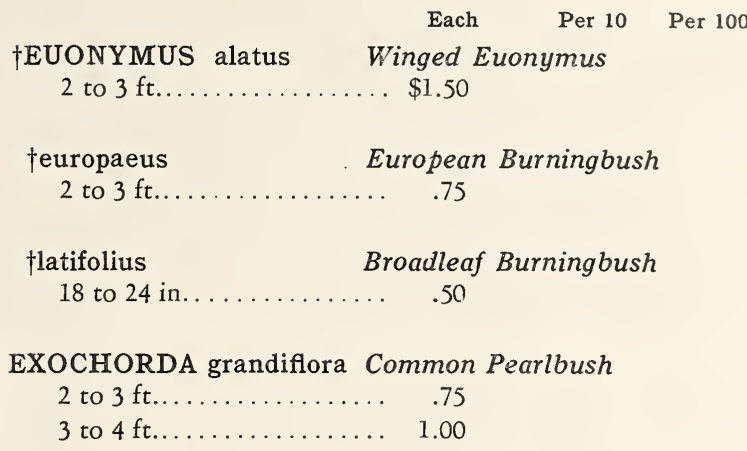

FORSYTHIA intermedia Border Forsythia

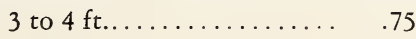

i. spectabilis Showy Border Forsythia 18 to 24 in.............. $\quad .60$

2 to $3 \mathrm{ft} \ldots \ldots \ldots \ldots \ldots . . .65$

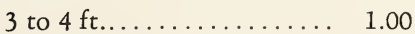

†suspensa fortunei Fortune Forsythia

2 to $3 \mathrm{ft} . \ldots \ldots \ldots \ldots \ldots . . . \ldots 0 \quad .60$

3 to $4 \mathrm{ft} \ldots \ldots \ldots \ldots \ldots . . . . . . . . .65$

†viridissima Greenstem Forsythia

2 to $3 \mathrm{ft} \ldots \ldots \ldots \ldots \ldots \ldots . \quad .60 \quad 5.00$

HAMAMELIS virginiana Common Witch-hazel

2 to $3 \mathrm{ft} . \ldots \ldots \ldots \ldots \ldots . . .75$

$\dagger$ HIBISCUS syriacus Shrub-althea

3 to $4 \mathrm{ft} \ldots \ldots \ldots \ldots \ldots \ldots . . .75$

Double Red Double Pink

Double White Double Blush Pink

HYDRANGEA arborescens grandiflora Snowhill Hydrangea

2 to $3 \mathrm{ft} \ldots \ldots \ldots \ldots \ldots . . . . . . .65 \quad 6.50$

3 to $4 \mathrm{ft} \ldots \ldots \ldots \ldots . . . . . .60 \quad 8.00$

4 to $5 \mathrm{ft} \ldots \ldots \ldots \ldots \ldots . . .600$

paniculata grandiflora Hydrangea Peegee

18 to 24 in............. $\quad .60 \quad 5.00 \quad 33.00$

2 to $3 \mathrm{ft} \ldots \ldots \ldots \ldots \ldots . .65 \quad . \ldots 50 . .60$

3 to $4 \mathrm{ft}$. Standards....... 1.00

HYPERICUM lobocarpum Gattinger Hypericum

3 to $4 \mathrm{ft} . \ldots \ldots \ldots \ldots \ldots . . . .50$

†ILEX verticillata Common Winterberry

18 to 24 in.............. $.75 \quad 6.50$ 


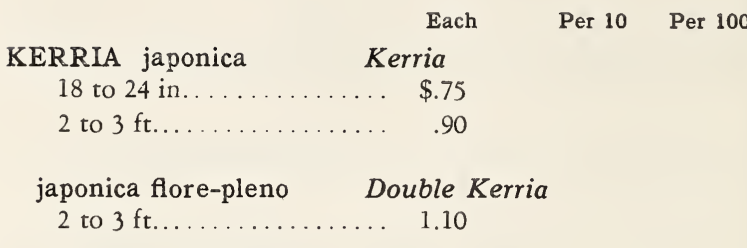

KOLKWITZIA amabilis Beauty Bush

18 to 24 in............. 2.50

2 to $3 \mathrm{ft} \ldots \ldots \ldots \ldots \ldots \ldots .4 .00$

†LIGUSTRUM amurense Amur Privet

$\begin{array}{llll}2 \text { to } 3 \mathrm{ft} \ldots \ldots \ldots \ldots \ldots \ldots \ldots & .40 & 2.50 & 18.00 \\ 3 \text { to } 4 \mathrm{ft} \ldots \ldots \ldots \ldots \ldots \ldots \ldots & .60 & 3.50 & 24.00 \\ 5 \text { to } 6 \mathrm{ft} \ldots \ldots \ldots \ldots \ldots \ldots & .90 & 6.00 & 45.00\end{array}$

\begin{tabular}{|c|c|c|}
\hline †ibota & Ibota Privet & \\
\hline 2 to $3 \mathrm{ft}$. & .40 & 3.00 \\
\hline 3 to $4 \mathrm{ft}$. & .50 & 4.50 \\
\hline
\end{tabular}

\begin{tabular}{|c|c|c|c|}
\hline \multicolumn{4}{|l|}{ †i. regelianum } \\
\hline 18 to 24 in.. & .50 & 4.00 & 33.00 \\
\hline 2 to $2 \frac{1}{2} \mathrm{ft} \ldots$ & .60 & 5.00 & 39.00 \\
\hline $2 \frac{1}{2}$ to $3 \mathrm{ft}$... & .70 & 6.00 & 45.00 \\
\hline 3 to $4 \mathrm{ft} \ldots$. & 1.00 & 8.00 & \\
\hline 4 to $5 \mathrm{ft} \ldots \ldots \ldots \ldots \ldots$ & 1.25 & 11.00 & \\
\hline †ovalifolium & \multicolumn{3}{|c|}{ California Privet } \\
\hline 18 to 24 in.. & .20 & 1.50 & 8.00 \\
\hline 2 to $3 \mathrm{ft} \ldots \ldots \ldots \ldots \ldots$ & .25 & 1.80 & 10.00 \\
\hline 3 to $4 \mathrm{ft} \ldots \ldots \ldots \ldots \ldots$ & .30 & 2.20 & 12.00 \\
\hline
\end{tabular}

LONICER A fragrantissima Winter Honeysuckle

2 to $3 \mathrm{ft} \ldots \ldots \ldots \ldots \ldots . .75$

\begin{tabular}{|c|c|c|c|}
\hline †morrowi & \multicolumn{3}{|c|}{ Morrow Honeysuckle } \\
\hline 2 to $3 \mathrm{ft} . . . .$. & .50 & 4.00 & 30.00 \\
\hline ruprechtiana & \multicolumn{3}{|c|}{ Manchurian Honeysuckle } \\
\hline 2 to $3 \mathrm{ft}$.. & .50 & 4.50 & \\
\hline tatarica & \multicolumn{3}{|c|}{ Tatarian Honeysuckle } \\
\hline 2 to $3 \mathrm{ft} \ldots$ & .50 & 4.00 & \\
\hline $\begin{array}{l}f t \text {. alba } \\
2 \text { to } 3 \mathrm{ft}\end{array}$ & \multicolumn{3}{|c|}{$\begin{array}{l}\text { White Tatarian Honeysuckle } \\
\ldots \quad .50\end{array}$} \\
\hline
\end{tabular}

\section{$\dagger$ †HILADELPHUS}

coronarius Sweet Mockorange

$\begin{array}{llll}2 \text { to } 3 \mathrm{ft} \ldots \ldots \ldots \ldots \ldots \ldots & .50 & 4.00 & 30.00 \\ 3 \text { to } 4 \mathrm{ft} \ldots \ldots \ldots \ldots \ldots & .60 & 4.50 & 33.00\end{array}$

c. aureus Golden Mockorange

15 to 18 in.............. .75 


$\uparrow^{\text {†PHILADELPHUS (Continued) }}{ }^{\text {Each }}$ Per $10 \quad$ Per 100

tgordonianus
4 to $5 \mathrm{ft} . \ldots \ldots \ldots \ldots \ldots \ldots . \ldots .75 \quad \$ 6.50$
tgrandiflorus
6 to $8 \mathrm{ft} \ldots \ldots \ldots \ldots \ldots \ldots$ Big Scentless Mockorange

\section{HYBRID MOCKORANGE}

Avalanche

2 to $3 \mathrm{ft} \ldots \ldots \ldots \ldots \ldots \ldots . .75$

Brachybotrys
2 to $3 \mathrm{ft} \ldots \ldots \ldots \ldots \ldots \ldots, 1.50$
3 to $4 \mathrm{ft} . \ldots \ldots \ldots \ldots \ldots, \quad 1.80$

\section{Glacier}

18 to 24 in.............. .85

\begin{tabular}{|c|c|c|c|}
\hline \multicolumn{4}{|l|}{ Lemoine } \\
\hline 15 to $18 \mathrm{in}$. & .50 & 4.50 & 40.00 \\
\hline 18 to 24 in. & .60 & 5.00 & 45.00 \\
\hline
\end{tabular}

\section{Mont Blanc}

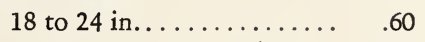

2 to $3 \mathrm{ft} \ldots \ldots \ldots \ldots \ldots \ldots . .75$

\section{Virginal}

18 to 24 in............. .75

2 to $3 \mathrm{ft} \ldots \ldots \ldots \ldots \ldots . . . .60$

3 to $4 \mathrm{ft} \ldots \ldots \ldots \ldots \ldots .1 .25$

\section{PHYSOCARPUS}

intermedius

Illinois Ninebark

2 to $3 \mathrm{ft} . \ldots \ldots \ldots \ldots \ldots .60 .60$

†opulifolia aureus Goldleaf Ninebark

3 to $4 \mathrm{ft} \ldots \ldots \ldots \ldots \ldots . . .50$

PRUNUS glandulosa

albiplena

Double Pinkflowering Almond

2 to $3 \mathrm{ft}$.

.. 1.00

tomentosa
2 to $3 \mathrm{ft} \ldots \ldots \ldots \ldots \ldots \ldots$
3 to $4 \mathrm{ft} \ldots \ldots \ldots \ldots \ldots \ldots$

triloba Flowering Plum

2 to $3 \mathrm{ft} \ldots \ldots \ldots \ldots \ldots . \quad .85 \quad 7.50$

\section{$\nmid$ RHODOTYPOS}

kerrioides

Jetbead

18 to 24 in............. $\quad .60$ 


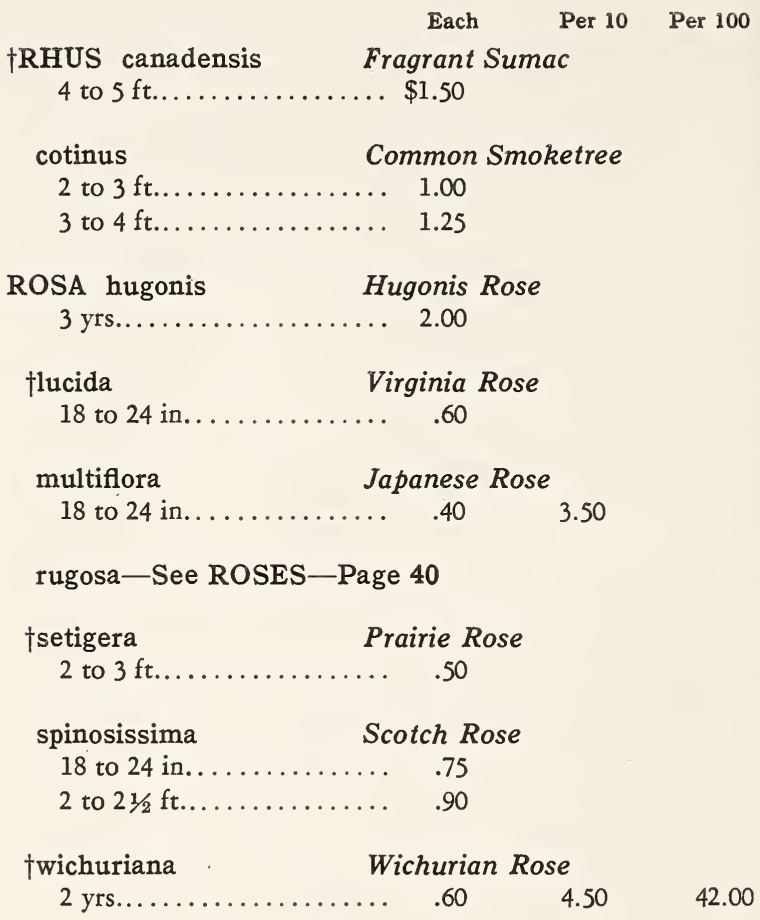

†SAMBUCUS canadensis American Elder

2 to $3 \mathrm{ft} . . . \ldots \ldots \ldots \ldots . . .50$

nigra laciniata
3 to $4 \mathrm{ft} . \ldots \ldots \ldots \ldots \ldots \ldots$

†SPIREA arguta Garland Spirea

2 to $3 \mathrm{ft} . \ldots \ldots \ldots \ldots \ldots . . .50$

†bumalda Bumalda Spirea

18 to 24 in............. $\quad .60 \quad 5.00 \quad 45.00$

†b. anthony waterer Anthony Waterer Spirea

12 to 15 in.............. .40

†b. froebeli Frobel Spirea

2 to $3 \mathrm{ft} . . . \ldots \ldots \ldots \ldots . .60 \quad 4.50$

douglasi
2 to $3 \mathrm{ft} \ldots \ldots \ldots \ldots \ldots \ldots$

japonica ovalifolia (callosa alba)

12 to 15 in.

White Japanese Spirea

.35

\begin{aligned} prunifolia & \multicolumn{2}{c}{ Bridalwreath } \\ 2 to $3 \mathrm{ft} \ldots \ldots \ldots \ldots \ldots \ldots & .60 \\ 3$ to $4 \mathrm{ft} \ldots \ldots \ldots \ldots \ldots \ldots & .75\end{aligned}$




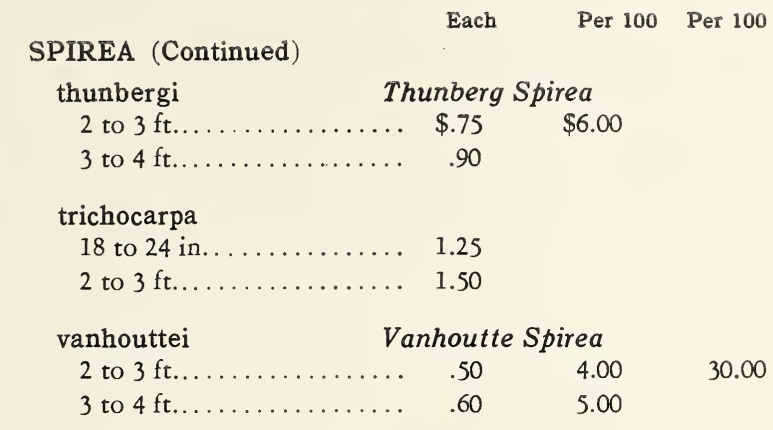

\section{STEPHANANDRA

flexuosa Cutleaf Stephanandra \\ 2 to $3 \mathrm{ft} \ldots \ldots \ldots \ldots \ldots . .60 \quad .60$ \\ STYRAX japonica Japanese Snowbell \\ 3 to $4 \mathrm{ft} . \ldots \ldots \ldots \ldots \ldots . .60$ \\ 4 to $5 \mathrm{ft} \ldots \ldots \ldots \ldots \ldots \ldots . .75$}

†SYMPHORICARPOS chenaulti

$\begin{array}{rrrr}18 \text { to } 24 \text { in.............. } & .75 & 6.50 & 55.00 \\ 2 \text { to } 3 \mathrm{ft} \ldots \ldots \ldots \ldots \ldots & 1.00 & 9.00 & \end{array}$

†racemosus Common Snowberry

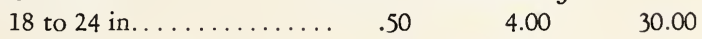

2 to $3 \mathrm{ft} \ldots \ldots \ldots \ldots \ldots . .60 \quad .60$

†vulgaris Coralberry

3 to $4 \mathrm{ft} \ldots \ldots \ldots \ldots \ldots .60 \quad .60 \quad 4.50 \quad 39.00$

SYRINGA chinensis

\section{(rothomagensis) Chinese Lilac}

2 to $3 \mathrm{ft} \ldots \ldots \ldots \ldots \ldots . . . . .90$

josikaea Hungarian Lilac

18 to 24 in.............. .60

persica Persian Lilac

3 to $4 \mathrm{ft} \ldots \ldots \ldots \ldots \ldots . \quad 1.00$

villosa Late Lilac

2 to $3 \mathrm{ft} . . . \ldots \ldots \ldots \ldots . . . .90$

†vulgaris Common Lilac

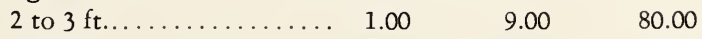

†v. alba Common White Lilac

2 to $3 \mathrm{ft} \ldots \ldots \ldots \ldots \ldots . . .60$

\section{HYBRID LILACS-Mixed}

These are all choice sorts which originally came from the Arnold Arboretum. The labels, however, have been lost so that we are unable to distinguish the varieties; therefore this very low price.

18 to 24 in............. 1.00

2. to $3 \mathrm{ft} \ldots \ldots \ldots \ldots \ldots . .25$ 


\begin{tabular}{|c|c|c|}
\hline †VACCINIUM & Each & Per 10 \\
\hline corymbosum & Highbush & Blueberry \\
\hline 2 to $3 \mathrm{ft}$. & $\ldots \$ 1.25$ & $\$ 11.00$ \\
\hline 3 to $4 \mathrm{ft}$. & 2.00 & \\
\hline
\end{tabular}

VIBURNUM americanum American Cranberrybush

2 to $3 \mathrm{ft} \ldots \ldots \ldots \ldots \ldots . . . \ldots \ldots$

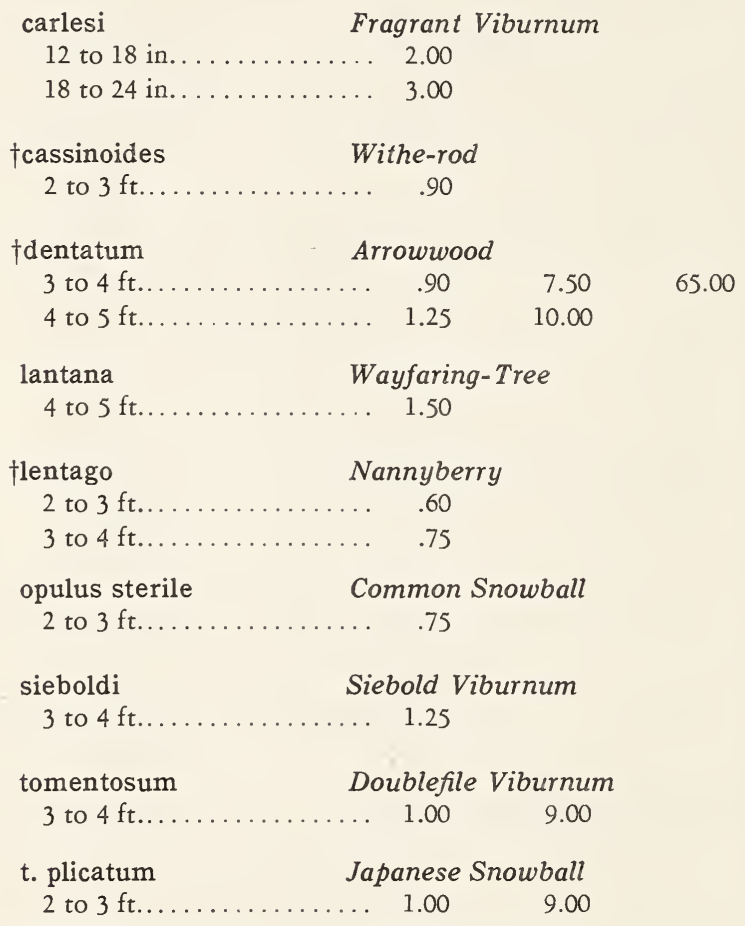

\section{WEIGELA floribunda Crimson Weigela}

2 to $3 \mathrm{ft} . \ldots \ldots \ldots \ldots \ldots . .60 \quad .50$

rosea Pink Weigela

18 to 24 in.............. .50

r. variegata Variegated Weigela

2 to $3 \mathrm{ft} \ldots \ldots \ldots \ldots \ldots . . .65$

\section{HYBRID VARIETIES} candida

2 to $3 \mathrm{ft} . \ldots \ldots \ldots \ldots \ldots . .50$

desboisi Desbois Weigela

2 to $3 \mathrm{ft} \ldots \ldots \ldots \ldots \ldots \ldots .60$

Eva Rathke

18 to 24 in

.60

ZANTHORHIZA apiifolia Yellowroot

12 to 15 in............. . 40 


\section{Evergreen Trees}

Evergreens will”be balled and burlapped (B. \& B.) without extra charge

\section{ABIES concolor}

2 to $2 \frac{1}{2} \mathrm{ft} \ldots \ldots \ldots \ldots \ldots .7 .00 \quad \$ 65.00$

$21 / 2$ to $3 \mathrm{ft} \ldots \ldots \ldots \ldots . . .6 .00 \quad 75.00$

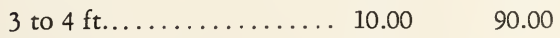

4 to $5 \mathrm{ft} \ldots \ldots \ldots \ldots \ldots .12 .00$

5 to $6 \mathrm{ft} \ldots \ldots \ldots \ldots \ldots .15 .00$

\section{CHAMAECYPARIS}

obtusa gracilis Slender Hinoki Cypress

2 to $21 / 2 \mathrm{ft} \ldots \ldots \ldots \ldots \ldots . \quad 7.00$

$21 / 2$ to $3 \mathrm{ft} \ldots \ldots \ldots \ldots \ldots . .6850$

3 to $31 / 2 \mathrm{ft} \ldots \ldots \ldots \ldots \ldots . \quad 9.50$

\begin{tabular}{|c|c|c|c|}
\hline $\begin{array}{l}\text { pisifera } \\
2 \text { to } 21 / 2 \mathrm{ft} .\end{array}$ & \multicolumn{2}{|c|}{ Sawara Retinospora } & \\
\hline $21 / 2$ to $3 \mathrm{ft}$. & 5.50 & & \\
\hline 3 to $4 \mathrm{ft}$.. & 6.00 & 55.00 & 500.00 \\
\hline 4 to $5 \mathrm{ft}$.. & 7.00 & 65.00 & 600.00 \\
\hline 5 to $6 \mathrm{ft} . .$. & 9.00 & & \\
\hline p. filifera & \multicolumn{2}{|c|}{ Thread Retinospora } & \\
\hline 18 to 24 in. & 3.75 & 35.00 & 270.00 \\
\hline 2 to $21 / 2 \mathrm{ft}$. & 4.75 & 45.00 & 375.00 \\
\hline $21 / 2$ to $3 \mathrm{ft}$. & 6.00 & 57.00 & 500.00 \\
\hline 3 to $4 \mathrm{ft}$.... & 7.00 & 67.50 & \\
\hline 4 to $5 \mathrm{ft} . .$. & $\ldots 10.00$ & & \\
\hline 5 to $6 \mathrm{ft} . .$. & .. 15.00 & & \\
\hline
\end{tabular}

*p. filifera aurea Golden Thread Retinospora

12 to 15 in. Spread....... 5.00

p. plumosa Plume Retinospora

\begin{tabular}{|c|c|c|c|}
\hline 18 to 24 in.. & 3.00 & 27.00 & 240.00 \\
\hline 2 to $21 / 2 \mathrm{ft} \ldots$ & 4.00 & 35.00 & \\
\hline $21 / 2$ to $3 \mathrm{ft} .$. & 5.00 & 48.00 & 450.00 \\
\hline 3 to $31 / 2 \mathrm{ft} . .$. & 6.00 & 55.00 & 500.00 \\
\hline $31 / 2$ to $4 \mathrm{ft} \ldots \ldots \ldots$ & 6.50 & 60.00 & 550.00 \\
\hline 4 to $41 / 2 \mathrm{ft}$... & 7.00 & 65.00 & 600.00 \\
\hline $41 / 2$ to $5 \mathrm{ft} . .$. & 8.00 & 75.00 & 725.00 \\
\hline 5 to $6 \mathrm{ft} \ldots \ldots \ldots \ldots$ & 9.00 & 81.00 & \\
\hline
\end{tabular}

p. plumosa argentea Silvertip Retinospora

15 to 18 in............. 2.75

18 to 24 in............... $3.50 \quad 30.00$

2 to $21 / 2 \mathrm{ft} \ldots \ldots \ldots \ldots \ldots . . .5 .50 \quad 40.00$

$21 / 2$ to $3 \mathrm{ft} \ldots \ldots \ldots \ldots \ldots .5 .50 \quad 50.00$

p. plumosa aurea Goldenplume Retinospora

$\begin{array}{lllll}18 \text { to } 24 \text { in............... } & 3.00 & 25.00 & 225.00 \\ 2 \text { to } 21 / 2 \mathrm{ft} \ldots \ldots \ldots \ldots \ldots & 4.00 & 35.00 & 300.00 \\ 21 / 2 \text { to } 3 \mathrm{ft} \ldots \ldots \ldots \ldots \ldots \ldots & 5.00 & 45.00 & 425.00 \\ 3 \text { to } 4 \mathrm{ft} \ldots \ldots \ldots \ldots \ldots \ldots & 6.00 & 55.00 & 525.00 \\ 4 \text { to } 5 \mathrm{ft} \ldots \ldots \ldots \ldots \ldots \ldots \ldots & 8.00 & 75.00 & \end{array}$

5 to $6 \mathrm{ft} \ldots \ldots \ldots \ldots \ldots . . .11 .00$ 
Each Per 10 Per 100

CHAMAECYPARIS (Continued)

\begin{tabular}{|c|c|c|c|}
\hline p. squarrosa & \multicolumn{2}{|c|}{ Moss Retinospora } & \\
\hline 18 to 24 in. . & $\ldots \$ 4.00$ & $\$ 35.00$ & \\
\hline 2 to $3 \mathrm{ft}$. & 5.00 & 45.00 & $\$ 425.00$ \\
\hline 3 to $4 \mathrm{ft}$. & 6.00 & 55.00 & 525.00 \\
\hline 4 to $5 \mathrm{ft}$. & 7.00 & & \\
\hline 5 to $6 \mathrm{ft} .$. & . 10.00 & & \\
\hline
\end{tabular}

p. sulphurea Sulphur Plume Retinospora

18 to 24 in........... $3.75 \quad 35.00$

2 to $3 \mathrm{ft} \ldots \ldots \ldots \ldots \ldots .5 .00$

3 to $4 \mathrm{ft} \ldots \ldots \ldots \ldots \ldots .6 .75$

*†JUNIPERUS chinensis pfitzeriana

Pfitzer Juniper

15 to 18 in. Spread....... $3.00 \quad 27.00$

18 to 24 in. Spread....... $4.00 \quad 38.00$

2 to $2 \frac{1}{2} \mathrm{ft}$. Spread ....... $5.50 \quad 50.00$

$21 / 2$ to $3 \mathrm{ft}$. Spread ....... 7.00

3 to $3 \frac{1}{2} \mathrm{ft}$. Spread ........ $10.00 \quad 95.00$

*communis aurea Golden Juniper

12 to 15 in........... 2.00

15 to $18 \mathrm{in} . \ldots \ldots \ldots \ldots \ldots . . .00$

18 to 24 in............ 4.00

c. cracovica

\begin{tabular}{|c|c|c|c|}
\hline 18 to 24 in............. & 2.50 & 22.50 & \\
\hline 2 to $21 / 2 \mathrm{ft} \ldots \ldots \ldots \ldots \ldots$ & 3.50 & 33.00 & \\
\hline $21 / 2$ to $3 \mathrm{ft} \ldots \ldots \ldots \ldots \ldots$ & 4.50 & 42.00 & \\
\hline 3 to $31 / 2 \mathrm{ft} . \ldots \ldots \ldots \ldots$ & 5.50 & & \\
\hline hibernica & h Juniper & & \\
\hline 15 to 18 in. . & 2.00 & 15.00 & 125.00 \\
\hline 18 to $24 \mathrm{in.} \mathrm{.}$ & 2.25 & 20.00 & 175.00 \\
\hline 2 to $21 / 2 \mathrm{ft} \ldots \ldots \ldots \ldots \ldots$ & 3.00 & 27.50 & 250.00 \\
\hline $21 / 2$ to $3 \mathrm{ft} \ldots \ldots \ldots$ & 4.00 & 35.00 & 300.00 \\
\hline 3 to $4 \mathrm{ft} \ldots \ldots \ldots \ldots \ldots$ & 5.00 & 45.00 & 400.00 \\
\hline
\end{tabular}

c. suecica

Swedish Juniper

18 to 24 in............ $2.50 \quad 20.00$

2 to $21 / 2 \mathrm{ft} \ldots \ldots \ldots \ldots \ldots \ldots \quad 3.50 \quad 30.00$

$21 / 2$ to $3 \mathrm{ft} \ldots \ldots \ldots \ldots \ldots .4 .50 \quad 40.00$

3 to $31 / 2 \mathrm{ft} . \ldots \ldots \ldots \ldots \ldots .5 .50 \quad 50.00$

$31 / 2$ to $4 \mathrm{ft} \ldots \ldots \ldots \ldots \ldots .6 .50$

4 to $5 \mathrm{ft} \ldots \ldots \ldots \ldots \ldots \ldots .7 .50$

c. suecica

Swedish Juniper

\section{UPRIGHT COMPACT FORM}

18 to 24 in............. $2.00 \quad 18.00$

2 to $2 \frac{1}{2} \mathrm{ft} \ldots \ldots \ldots \ldots \ldots .2 .75 \quad 24.50$

$21 / 2$ to $3 \mathrm{ft} \ldots \ldots \ldots \ldots \ldots .3 .50 \quad 32.50$

300.00

3 to $31 / 2 \mathrm{ft} \ldots \ldots \ldots \ldots \ldots .4 .00$

$37.50 \quad 350.00$

$31 / 2$ to $4 \mathrm{ft} \ldots \ldots \ldots \ldots \ldots . . \ldots .75$

45.00

4 to $5 \mathrm{ft} \ldots \ldots \ldots \ldots \ldots \ldots .6 .00$

5 to $6 \mathrm{ft} \ldots \ldots \ldots \ldots \ldots .7 .50$ 


\section{Each Per $10 \quad$ Per 100}

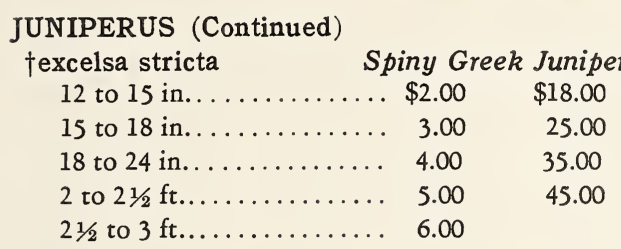

\section{*horizontalis douglasi Waukegan Juniper} 12 to 15 in................ $3.00 \quad 27.50$

15 to 18 in............ 3.50

18 to 24 in........... 4.00

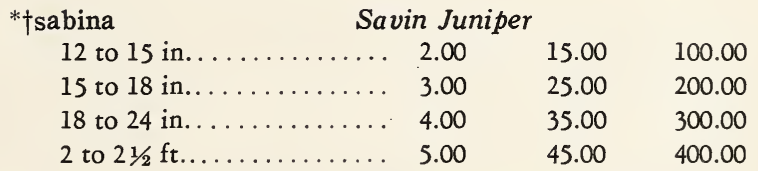

*s. tamariscifolia Tamarix Savin Juniper

12 to 15 in.......... 3.00

15 to 18 in........... 4.00

18 to 24 in........... 5.00

2 to $21 / 2 \mathrm{ft} \ldots \ldots \ldots \ldots \ldots .6 .00$

* †virginalis globosa Globe Chinese Juniper

12 to 15 in.......... $3.00 \quad 27.50$

18 to 24 in........... 7.50

\begin{tabular}{|c|c|c|}
\hline †virginiana & Redcedar & \\
\hline 2 to $21 / 2 \mathrm{ft}$. & 3.00 & 27.00 \\
\hline $21 / 2$ to $3 \mathrm{ft}$. & 4.00 & 37.50 \\
\hline 3 to $31 / 2 \mathrm{ft}$. & 5.00 & 47.50 \\
\hline $31 / 2$ to $4 \mathrm{ft}$. & 6.00 & \\
\hline 4 to $5 \mathrm{ft} . .$. & 7.00 & 65.00 \\
\hline 5 to $6 \mathrm{ft} . .$. & 9.00 & \\
\hline 6 to $7 \mathrm{ft} . .$. & .. 13.00 & \\
\hline 7 to $8 \mathrm{ft} . .$. & . . 16.00 & \\
\hline 8 to $9 \mathrm{ft} . .$. & .. 25.00 & \\
\hline 9 to $10 \mathrm{ft}$. & .. 30.00 & \\
\hline 10 to $11 \mathrm{ft}$. & ... 35.00 & \\
\hline 12 to $13 \mathrm{ft}$. & .. 50.00 & \\
\hline
\end{tabular}

†v. glauca Silver Redcedar

2 to $21 / 2 \mathrm{ft} . \ldots \ldots \ldots \ldots \ldots .5 .00$

$21 / 2$ to $3 \mathrm{ft} \ldots \ldots \ldots \ldots \ldots .6 .00$

†PICEA canadensis White Spruce

2 to $21 / 2 \mathrm{ft} \ldots \ldots \ldots \ldots \ldots .3 .75 \quad 35.00$

$21 / 2$ to $3 \mathrm{ft} \ldots \ldots \ldots \ldots \ldots .4 .75$

†excelsa

Norway Spruce

$\begin{array}{lllll}18 \text { to } 24 \text { in.............. } & 2.25 & 20.00 & 175.00 \\ 2 \text { to } 3 \mathrm{ft} . \ldots \ldots \ldots \ldots \ldots \ldots & 2.75 & 25.00 & 225.00 \\ 3 \text { to } 4 \mathrm{ft} . \ldots \ldots \ldots \ldots \ldots \ldots & 4.50 & 40.00 & 350.00 \\ 4 \text { to } 5 \mathrm{ft} . \ldots \ldots \ldots \ldots \ldots \ldots & 5.50 & 50.00 & 475.00\end{array}$




Each Per 10 Per 100

\section{PICEA (Continued)}

* tglauca conica Dwarf Alberta Spruce

10 to 12 in............ $\$ 3.50 \quad \$ 32.50 \quad \$ 300.00$

12 to 14 in.............. $4.00 \quad 37.50 \quad 350.00$

14 to 16 in............... $4.50 \quad 42.50 \quad 400.00$

16 to 18 in.............. $5.00 \quad 47.50 \quad 450.00$

18 to 20 in.............. $5.50 \quad 52.50 \quad 500.00$

20 to 22 in.............. $6.00 \quad 57.50 \quad 550.00$

22 to 24 in.............. $8.00 \quad 77.50 \quad 750.00$

24 to 26 in.............. $10.00 \quad 95.00$

26 to 28 in............. 12.00

\begin{tabular}{|c|c|}
\hline mariana & Black Spruce \\
\hline 18 to 24 in. & $\begin{array}{l}2.25 \\
3.00\end{array}$ \\
\hline $21 / 2$ to $3 \mathrm{ft}$. & 4.00 \\
\hline
\end{tabular}

tpungens Colorado Spruce
18 to 24 in............. $4.00 \quad 35.00$
2 to $21 / 2 \mathrm{ft} \ldots \ldots \ldots \ldots . .6 .600 \quad 6.00 \quad 55.00$
$21 / 2$ to $3 \mathrm{ft} \ldots \ldots \ldots \ldots . . . . .67 .00 \quad 65.00$
3 to $4 \mathrm{ft} \ldots \ldots \ldots \ldots \ldots . . . . .6 .00 \quad 75.00$
4 to $5 \mathrm{ft} \ldots \ldots \ldots \ldots . . . . .690$
5 to $6 \mathrm{ft} \ldots \ldots \ldots \ldots . . . \ldots 11.00$

\begin{tabular}{|c|c|c|}
\hline †p. glauca & \multicolumn{2}{|c|}{ Blue Colorado Spruce } \\
\hline 18 to 24 in. & 6.00 & 55.00 \\
\hline 2 to $2 \frac{1}{2} \mathrm{ft} .$. & 8.00 & 75.00 \\
\hline $21 / 2$ to $3 \mathrm{ft}$.. & 10.00 & 95.00 \\
\hline 3 to $4 \mathrm{ft}$... & .. 14.00 & 135.00 \\
\hline 4 to $5 \mathrm{ft} .$. & 18.00 & \\
\hline 5 to $6 \mathrm{ft}$.... & 21.00 & \\
\hline
\end{tabular}

\section{PINUS banksiana Jack Pine}

2 to $3 \mathrm{ft...............} 1.50$

\begin{tabular}{|c|c|}
\hline tcembra & Swiss Stone Pine \\
\hline 2 to $21 / 2 \mathrm{ft}$. & 7.00 \\
\hline $21 / 2$ to $3 \mathrm{ft}$.. & 9.00 \\
\hline 3 to $31 / 2 \mathrm{ft}$. & 11.00 \\
\hline
\end{tabular}

\begin{tabular}{|c|c|c|c|}
\hline${ }^{*} \dagger$ montana mughus & Mugho Pine & & \\
\hline 12 to 15 in... & 3.00 & 27.00 & 250.00 \\
\hline 15 to 18 in. . & 4.00 & 37.50 & 350.00 \\
\hline 18 to 24 in. . & 5.50 & 50.00 & 450.00 \\
\hline 2 to $21 / 2 \mathrm{ft}$.. & 7.50 & & \\
\hline $21 / 2$ to $3 \mathrm{ft}$... & 10.00 & & \\
\hline
\end{tabular}

tnigra
18 to $24 \mathrm{in} . \ldots \ldots \ldots \ldots \ldots$
2 to $2 \frac{1}{2} \mathrm{ft} \ldots \ldots \ldots \ldots \ldots$

resinosa Red Pine

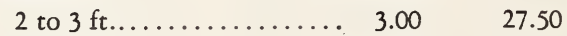

3 to $4 \mathrm{ft} \ldots \ldots \ldots \ldots \ldots . . . .60$ 
Each Per 10 Per 100

\section{PINUS (Continued)}

\section{†strobus \\ White Pine}

These pines have been sheared and are exceptionally heavy and bushy.
3 to $31 / 2 \mathrm{ft} \ldots \ldots \ldots \ldots \ldots \ldots+.50$
$31 / 2$ to $4 \mathrm{ft} \ldots \ldots \ldots \ldots \ldots . . \ldots .25$

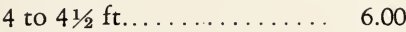
$\$ 50.00$
$41 / 2$ to $5 \mathrm{ft} \ldots \ldots \ldots \ldots \ldots .6 .75$
57.50
5 to $6 \mathrm{ft} \ldots \ldots \ldots \ldots \ldots \ldots . \ldots \ldots$
6 to $7 \mathrm{ft} \ldots \ldots \ldots \ldots \ldots . \ldots 12.00$
7 to $8 \mathrm{ft} \ldots \ldots \ldots \ldots \ldots \ldots 15.00$

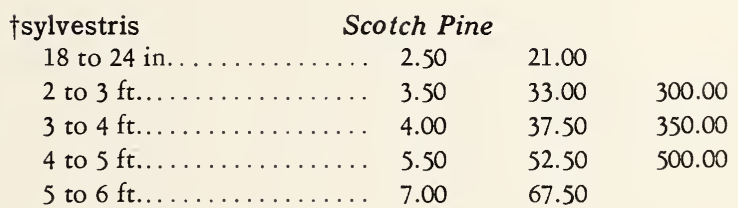

\section{$\dagger$ PSEUDOTSUGA douglasi Douglas Fir}

$\begin{array}{lllll}2 \text { to } 3 \mathrm{ft} \ldots \ldots \ldots \ldots \ldots \ldots \ldots \ldots \ldots \ldots & 5.00 & 48.00 & 450.00 \\ 3 \text { to } 4 \mathrm{ft} \ldots \ldots \ldots \ldots \ldots & 6.50 & 62.50 & 600.00 \\ 4 \text { to } 5 \mathrm{ft} \ldots \ldots \ldots \ldots \ldots & 9.00 & & \end{array}$

\section{RETINOSPORA-See CHAMAECYPARIS}

\section{*TAXUS canadensis Canada Yew}

$\begin{array}{llll}12 \text { to } 15 \text { in. Spread........ } & 2.50 & 22.50 & 200.00 \\ 15 \text { to } 18 \text { in. Spread........ } & 3.00 & 27.50 & 250.00 \\ 18 \text { to } 24 \text { in. Spread........ } & 3.50 & 33.00 & 300.00\end{array}$

\section{tcuspidata}

\section{(Spreading Form) Japanese Yew}

12 to 15 in. Spread....... $3.00 \quad 27.50$

15 to 18 in. Spread....... $4.00 \quad 36.00$

18 to 24 in. Spread....... $5.00 \quad 45.00$

2 to $21 / 2 \mathrm{ft}$. Spread ........ $7.50 \quad 70.00$

$21 / 2$ to $3 \mathrm{ft}$. Spread ....... 12.00

†c. capitata
(Upright Form)
Japanese Yew

$21 / 2$ to $3 \mathrm{ft} \ldots \ldots \ldots \ldots \ldots . . .100$

\section{*†c. nana (brevifolia) Dwarf Japanese Yew}

\section{(Upright Compact Form)}

12 to 15 in.......... 4.00

15 to 18 in.......... 5.00

18 to 24 in........... 8.00

\section{(Spreading Form)}

\begin{tabular}{|c|c|}
\hline 12 to 15 in. & 4.00 \\
\hline 15 to 18 in. & 5.00 \\
\hline 18 to $21 \mathrm{in.}$ & 8.00 \\
\hline 21 to $24 \mathrm{in.}$ & 12.00 \\
\hline to $27 \mathrm{in}$. & 16.00 \\
\hline
\end{tabular}




\begin{tabular}{|c|c|c|c|}
\hline & Each & Per 10 & Per 100 \\
\hline †THUJA occidentalis & \multicolumn{3}{|c|}{ American Arborvitae } \\
\hline 2 to $3 \mathrm{ft} \ldots .$. & $\ldots \$ 3.50$ & $\$ 30.00$ & $\$ 250.00$ \\
\hline 3 to $4 \mathrm{ft} .$. & 4.50 & 40.00 & 375.00 \\
\hline 4 to $5 \mathrm{ft} . .$. & 6.00 & 55.00 & 500.00 \\
\hline 5 to $6 \mathrm{ft} .$. & 8.00 & & \\
\hline 6 to $7 \mathrm{ft} .$. & . . 10.00 & & \\
\hline oc. compacta & \multicolumn{3}{|c|}{ Parsons Arborvitae } \\
\hline 12 to $15 \mathrm{in.}$ & 2.00 & 15.00 & 125.00 \\
\hline 15 to $18 \mathrm{in.}$. & 2.50 & 22.50 & 200.00 \\
\hline 18 to 24 in. . . . & 3.50 & 32.50 & 300.00 \\
\hline 2 to $2 \frac{1}{2} \mathrm{ft} \ldots$ & 4.00 & 37.50 & \\
\hline
\end{tabular}

†oc. douglasi pyramidalis Douglas Pyramidal Arborvitae

\begin{tabular}{|c|c|c|}
\hline 18 to 24 in..... & 3.00 & 27.50 \\
\hline 2 to $21 / 2 \mathrm{ft} \ldots \ldots \ldots \ldots \ldots$ & 3.50 & 32.50 \\
\hline $21 / 2$ to $3 \mathrm{ft} \ldots \ldots \ldots \ldots \ldots$ & 4.50 & 42.50 \\
\hline 3 to $31 / 2 \mathrm{ft} \ldots$ & 5.00 & 47.50 \\
\hline $31 / 2$ to $4 \mathrm{ft} .$. & 6.00 & 57.50 \\
\hline 4 to $41 / 2 \mathrm{ft} \ldots$. & 7.00 & 67.50 \\
\hline $5 \mathrm{ft}$ & 8.00 & 77.50 \\
\hline $\mathrm{ft} \ldots . . \mathrm{s}$ & 9.00 & 87.50 \\
\hline
\end{tabular}

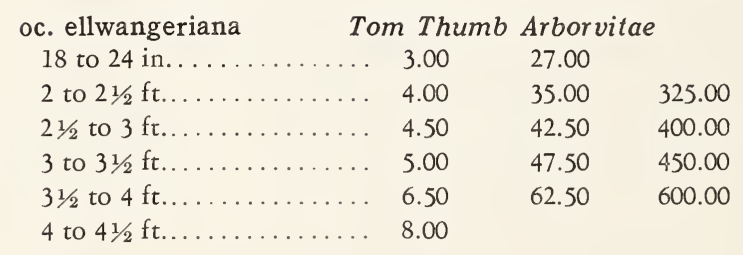

\section{oc. filiformis Threadleaf Arborvitae}

18 to 24 in............ 8.00

\begin{tabular}{|c|c|c|c|}
\hline oc. globosa & \multicolumn{3}{|c|}{ American Globe Arborvitae } \\
\hline 12 to 15 in. & 2.00 & 17.50 & 150.00 \\
\hline 15 to 1 & 2.50 & 22.50 & 200.00 \\
\hline $18 \mathrm{t}$ & 3.00 & 27.50 & 50.00 \\
\hline $2 t$ & 3.50 & 32.50 & 300.00 \\
\hline
\end{tabular}

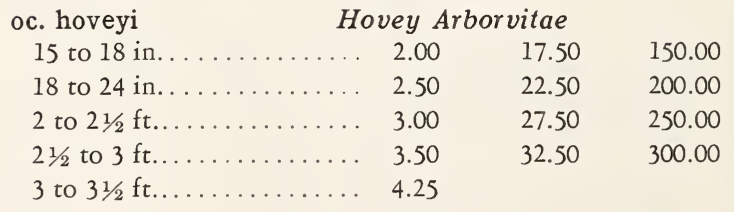

\begin{tabular}{|c|c|c|c|}
\hline oc. lutea & \multicolumn{3}{|c|}{ George Peabody Arborvitae } \\
\hline 18 to 24 in. & 3.50 & 32.50 & 300.00 \\
\hline 2 to $3 \mathrm{ft}$. & 4.50 & 42.50 & 400.00 \\
\hline 3 to $4 \mathrm{ft}$. & 5.50 & 52.50 & \\
\hline 4 to $5 \mathrm{ft} .$. & 7.00 & 67.50 & \\
\hline
\end{tabular}


Each Per 10 Per 100

THUJA (Continued)

†oc. pyramidalis American Pyramidal Arborvitae 2 to $21 / 2 \mathrm{ft} \ldots \ldots \ldots \ldots \ldots . \$ 4.00 \quad \$ 35.00$

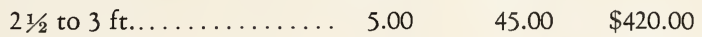

$\begin{array}{lllll}3 \text { to } 31 / 2 \mathrm{ft} \ldots \ldots \ldots \ldots & 6.00 & 57.00 \quad 540.00\end{array}$

$31 / 2$ to $4 \mathrm{ft} \ldots \ldots \ldots \ldots . .67 .00 \quad 67.50 \quad 650.00$

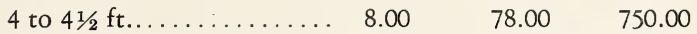

$41 / 2$ to $5 \mathrm{ft} \ldots \ldots \ldots \ldots . .6 .50 \quad 90.00 \quad 850.00$

5 to $51 / 2 \mathrm{ft} \ldots \ldots \ldots \ldots \ldots . .11 .00 \quad 100.00 \quad 900.00$

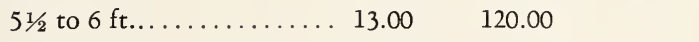

6 to $7 \mathrm{ft} \ldots \ldots \ldots \ldots \ldots . . .15 .00$

oc. reidi Reid Arborvitae

18 to 24 in............. $4.50 \quad 40.00$

2 to $21 / 2 \mathrm{ft} \ldots \ldots \ldots \ldots \ldots .5 .50 \quad 52.50 \quad 500.00$

$21 / 2$ to $3 \mathrm{ft} \ldots \ldots \ldots \ldots \ldots . \ldots \ldots$

3 to $31 / 2 \mathrm{ft} \ldots \ldots \ldots \ldots \ldots .9 .00$

oc. rosenthali Rosenthal Arborvitae

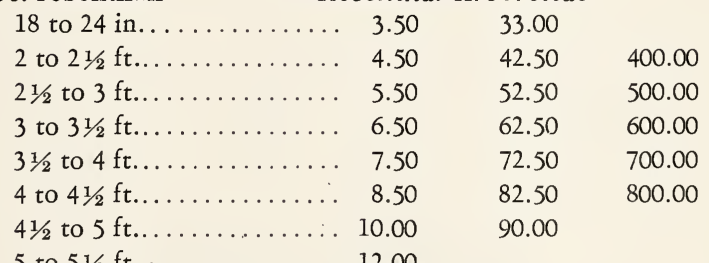

5 to $51 / 2 \mathrm{ft} . \ldots \ldots \ldots \ldots \ldots . . .12 .00$

oc. siberica-See oc. wareana

\begin{tabular}{l|ccc} 
oc. vervaeneana & \multicolumn{3}{c}{ Vervaene Arborvitae } \\
2 to $21 / 2 \mathrm{ft} \ldots \ldots \ldots \ldots \ldots \ldots$ & 4.00 & 37.50 & \\
$21 / 2$ to $3 \mathrm{ft} \ldots \ldots \ldots \ldots \ldots \ldots$ & 5.00 & 47.50 & \\
3 to $31 / 2 \mathrm{ft} \ldots \ldots \ldots \ldots \ldots \ldots$ & 6.00 & 57.50 & \\
$31 / 2$ to $4 \mathrm{ft} \ldots \ldots \ldots \ldots \ldots \ldots$ & 7.00 & 67.50 & 650.00 \\
4 to $41 / 2 \mathrm{ft} \ldots \ldots \ldots \ldots \ldots$ & 8.00 & 77.50 & 750.00 \\
$41 / 2$ to $5 \mathrm{ft} \ldots \ldots \ldots \ldots \ldots$ & 9.00 & 87.50 & \\
5 to $6 \mathrm{ft} \ldots \ldots \ldots \ldots \ldots \ldots$ & 10.00 & 95.00 &
\end{tabular}

†oc. wareana Ware Arborvitae (Siberian)

\begin{tabular}{|c|c|c|c|}
\hline 15 to $18 \mathrm{in.}$. & 2.50 & 22.50 & 200.00 \\
\hline 18 to 24 in... & 3.50 & 33.00 & 300.00 \\
\hline 2 to $21 / 2 \mathrm{ft} .$. & 4.50 & 42.50 & 400.00 \\
\hline $21 / 2$ to $3 \mathrm{ft} .$. & 5.50 & 52.50 & 500.00 \\
\hline $31 \mathrm{ft}$ & 7.00 & 67.50 & 650.00 \\
\hline$\Delta \mathrm{ft}_{\mathrm{t}}$ & 8.00 & 78.00 & \\
\hline
\end{tabular}

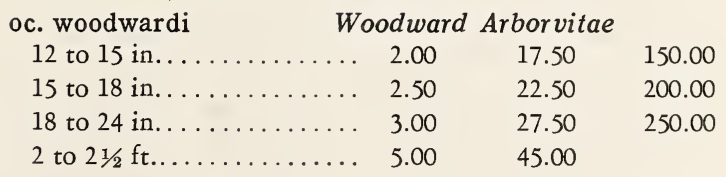


THUJA (Continued)

Each Per 10 Per 100

\begin{tabular}{crr} 
orientalis & \multicolumn{3}{c}{ Oriental } & Arborvitae \\
18 to 24 in............ & $\ldots 2.25$ & $\$ 20.00$ \\
2 to $21 / 2 \mathrm{ft} \ldots \ldots \ldots \ldots \ldots \ldots$ & 2.75 & 25.00 \\
$21 / 2$ to $3 \mathrm{ft} \ldots \ldots \ldots \ldots \ldots \ldots$ & 3.25 & 30.00
\end{tabular}

\section{TSUGA canadensis Canada Hemlock}

18 to 24 in.

3.00

27.50

250.00

2 to $21 / 2 \mathrm{ft}$.

$4.00 \quad 37.50$

350.00

$21 / 2$ to $3 \mathrm{ft}$.

5.25

50.00

475.00

3 to $31 / 2 \mathrm{ft}$.

6.50

62.50

600.00

$31 / 2$ to $4 \mathrm{ft}$.

8.50

82.50

4 to $4 \frac{1}{2} \mathrm{ft}$.

11.00

105.00

$41 / 2$ to $5 \mathrm{ft}$.

13.00

5 to $51 / 2 \mathrm{ft}$.

16.00

$51 / 2$ to $6 \mathrm{ft}$.

18.00

6 to $7 \mathrm{ft}$.

20.00

caroliniana

Carolina Hemlock

3 to $31 / 2 \mathrm{ft} . \ldots \ldots \ldots \ldots \ldots .6 .00$

$31 / 2$ to $4 \mathrm{ft} \ldots \ldots \ldots \ldots \ldots . . \ldots . . . \ldots$

4 to $4 \frac{1}{2} \mathrm{ft} \ldots \ldots \ldots \ldots \ldots . . . .60$

$41 / 2$ to $5 \mathrm{ft} \ldots \ldots \ldots \ldots \ldots . . .60$

5 to $6 \mathrm{ft} \ldots \ldots \ldots \ldots \ldots \ldots$

\section{Evergreen Shrubs}

\section{BUXUS sempervirens Common Box}
12 to 15 in.
2.50
15 to 18 in............ 3.00
18 to 24 in............ 3.50

*CALLUNA vulgaris alba hammondi

Hammond White Heather

6 to 8 in........... $.75 \quad 6.00$

\section{*DAPHNE cneorum Rose Daphne}
4 to 6 in. Spread.
.75
7.00
60.00
6 to 8 in. Spread.
1.25
11.00
*ERICA stricta
4 to 6 in............ .75
*vagans Cornish Heath
4 to 6 in............. .75

\section{EUONYMUS radicans Wintercreeper}

2 yrs................ $60 \quad 5.00$

r. carrieri Glossy Wintercreeper

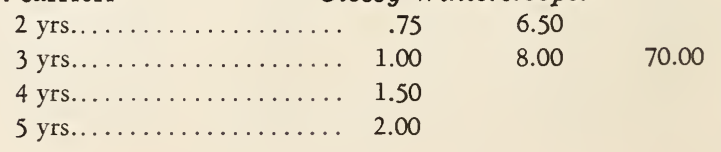




\section{Each Per 10 Per 100}

\section{EUONYMUS (Continued)}

r. colorata

\begin{tabular}{|c|c|c|}
\hline & $\$ .75$ & $\$ 6.00$ \\
\hline & .90 & 8.00 \\
\hline
\end{tabular}

This variety was introduced by the Arnold Arboretum from whom we procured our stock. We have been growing it for several years and have found it perfectly hardy. The foliage, which turns to a beautiful bronze in the Fall, makes it particularly desirable.

\begin{tabular}{|c|c|c|c|}
\hline r. vegetus & \multicolumn{3}{|c|}{ Bigleaf Wintercreeper } \\
\hline 2 yrs... & $\ldots$ & 6.00 & 48.00 \\
\hline 3 yrs.. & 1.00 & 8.00 & 70.00 \\
\hline 4 yrs... & 1.50 & & \\
\hline
\end{tabular}

\section{ILEX glabra Inkberry}

12 to 15 in. Clumps....... 1.50

15 to 18 in. Clumps...... 2.50

18 to 24 in. Clumps...... 3.00

\section{KALMIA latifolia Mountain Laurel}

\begin{tabular}{|c|c|c|}
\hline 18 to 24 in. & 3.50 & 30.00 \\
\hline 2 to $21 / 2 \mathrm{ft}$. & 4.00 & 35.00 \\
\hline $21 / 2$ to $3 \mathrm{ft}$. & 5.00 & 45. \\
\hline 3 to $31 / 2 \mathrm{ft}$. . & 7.00 & 65.0 \\
\hline
\end{tabular}

\section{LEUCOTHOE catesbaei Drooping Leucothoe}

12 to 15 in............ $2.00 \quad 17.50$

15 to 18 in............. $2.50 \quad 22.50$

18 to 24 in............ $3.50 \quad 32.50$

\section{$\nmid$ PACHYSANDRA \\ terminalis Japanese Pachysandra}

$\begin{array}{llll}\text { Field-grown.............. } & .35 & 2.50 & 18.00\end{array}$

\section{PIERIS floribunda Mountain Andromeda}

12 to 15 in. Spread........ $3.50 \quad 32.50$

15 to 18 in. Spread....... $4.50 \quad 40.00$

18 to 24 in. Spread....... 6.00

†VINCA minor Common Periwinkle

$\begin{array}{llll}\text { Field-grown............... } & .25 & 2.00 & 15.00\end{array}$

\section{Rbododendrons}

To have the best results with Rhododendrons, your soil should be acid. If you are in doubt, we will be glad to make a test and advise the best method of procedure to insure success. 


\section{Each Per 10 Per 100}

HARDY HYBRID VARIETIES:

12 to 18 in............. $\$ 7.50$

Catawbiense album-White, fast grower

Catawbiense grandiflorum-Rosy-lilac

Dr. H. C. Dresselhuys-Analine red

Everestianum-Rosy-lilac

F. L. Ames (Amphion) Clear pink, white eye

Mrs. C. S. Sargent-Rosy red or deep pink

President Lincoln-Lilac pink, brown eye

Roseum elegans-Clear rose-pink

\section{MIXED HYBRID RHODODENDRONS}

$\begin{array}{llll}12 \text { to } 15 \text { in.............. } & 3.50 & 32.50 \\ 15 \text { to } 18 \text { in.............. } & 4.50 & 42.50 \\ 18 \text { to } 24 \text { in............ } & 5.50 & 52.50 \\ 2 \text { to } 21 / 2 \mathrm{ft} \ldots \ldots \ldots \ldots \ldots & 7.00 & 67.50\end{array}$

These plants are grown from seeds of Hybrid Rhododendrons, shading from red, pink, to white. They grow much stronger and bushier than the grafted hybrids, and are perfectly hardy.

\section{RHODODENDRON}

carolinianum

Carolina Rhododendron

18 to 24 in............ $3.75 \quad 35.00$

2 to $21 / 2 \mathrm{ft} \ldots \ldots \ldots \ldots \ldots .4 .50$

$21 / 2$ to $3 \mathrm{ft} \ldots \ldots \ldots \ldots \ldots .6 .00$

3 to $31 / 2 \mathrm{ft} \ldots \ldots \ldots \ldots \ldots .7 .50$

\section{RHODODENDRON}

\section{catawbiense Catawba Rhododendron}

15 to 18 in............ $2.50 \quad 22.50$

18 to 24 in........... $3.00 \quad 27.50$

2 to $21 / 2 \mathrm{ft} \ldots \ldots \ldots \ldots \ldots .4 .00$

$21 / 2$ to $3 \mathrm{ft} \ldots \ldots \ldots \ldots \ldots .5 .00$

\section{RHODODENDRON}

\section{maximum}

15 to 18 in. . . ........ 1.50

18 to 24 in. ........... 2.00

2 to $21 / 2 \mathrm{ft} . \ldots \ldots \ldots \ldots \ldots . . . .60$

$21 / 2$ to $3 \mathrm{ft} . \ldots \ldots \ldots \ldots \ldots \ldots \quad 4.00$

3 to $31 / 2 \mathrm{ft} \ldots \ldots \ldots \ldots \ldots \ldots .5 .00$

$31 / 2$ to $4 \mathrm{ft} . \ldots \ldots \ldots \ldots \ldots .6 .00$

4 to $5 \mathrm{ft} . \ldots \ldots \ldots \ldots \ldots \ldots . . . .60$

5 to $6 \mathrm{ft} \ldots \ldots \ldots \ldots \ldots \ldots . . .00$

\section{Vines and Climbing Plants}

ACTINIDIA arguta

2 yrs.............. 1.00

\section{†AMPELOPSIS} quinquefolia

3 yrs.
Virginia Creeper

$.60 \quad 4.50$


AMPELOPSIS (Continued)

Each Per 10 Per 100

tricuspidata (veitchi) Japanese Creeper

2 yrs. Pot Grown........ \$.60 \$5.50

ARISTOLOCHIA sipho Dutchmans-pipe

4 yrs............ $1.50 \quad 12.50$

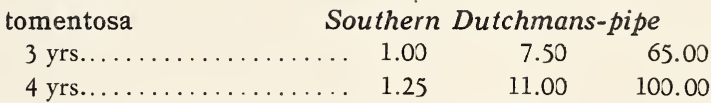

BIGNONIA radicans Trumpetcreeper

3 yrs.............. .50 4.50

BOSTON IVY-See Ampelopsis tricuspidata

CELASTRUS orbiculatus Oriental Bittersweet

3 yrs.............. 75

scandens American Bittersweet

2 yrs.................60

†CLEMATIS paniculata' Sweet Autumn Clematis

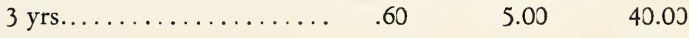

4 yrs............. $75 \quad 6.00 \quad 48.00$

HEDERA helix English Ivy

From 3 in. Pots.......... $\quad 60 \quad 5.00 \quad 45.00$

LONICERA japonica Yellownet Japanese aureoreticulata Honeysuckle

3 yrs............... .50

j. halliana

Hall Japanese Honeysuckle

4 yrs............... $60 \quad 4.50$

sempervirens Trumpet Honeysuckle

3 yrs............. $50 \quad 3.50 \quad 30.00$

LYCIUM chinense Chinese Matrimony-Vine

2 yrs.................50

PUERARIA thunbergiana Kudzu-bean

2 yrs.............. 50

WISTERIA sinensis Chinese Wisteria

2 yrs.......................... 60

3 yrs............... $\quad .75 \quad 6.00$

\section{Hardy Perennials}

ACHILLEA

Yarrow

*millefolium-Common Yarrow .25 \& 2.20

ptarmica - "The Pearl"...... .25 2.20

p. Perry White.......... $\quad .30 \quad 2.40$ 


\section{ACONITUM}

\section{Each}

Per 10

Per 100

autumnale-Autumn Monks-

hood ................ \$.50 \$4.00

fischeri-Azure Monkshood... $\quad .40 \quad 3.50$

napellus-Aconite........... $.35 \quad 2.70$

\section{AJUGA \\ Bugle}

*genevensis-Geneva Bugle.... $\quad .30$

\section{ALTHAEA rosea Hollyhock}

Double varieties:

Red, Deep Rose, Newport

Pink, White and Yellow. .

Single varieties:

Pink, White, Yellow and

Salmon............... .25

$2.20 \quad 15.00$

\section{ALYSSUM}

\section{Alyssum}

*saxatile compactum - Dwarf

Goldentuft.

\section{ANCHUSA}

\section{Bugloss}

italica Dropmore-Dropmore

Bugloss............... $\quad .30$

$2.40 \quad 18.00$

\section{ANEMONE}

\section{Anemone}

japonica alba-White Japanese

Anemone............... .30

j. Rubra-Red Japanese Anem-

one............... $\quad .30 \quad 2.40$

\section{AQUILEGIA}

Columbine

*caerulea-Colorado Columbine $\quad .30$

*chrysantha-Golden Columbine $\quad .30$

*long spurred hybrids....... $\quad .30$

\section{ARABIS}

\section{Rockcress}

*alpina-Alpine Rockcress..... $\quad .25$

\section{ARENARIA}

\section{Sandwort}

*verna caespitosa-Moss Sand-

wort...............35

\section{ARMERIA Thrift}

*formosa alba ........... .25

$*_{f}$ rosea ............... . .25

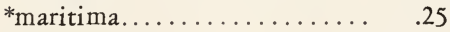

\section{ARTEMISIA}

Wormwood

abrotanum-Southernwood... $\quad .50 \quad 4.50$

lactiflora-White Mugwort... $\quad .35 \quad 2.70$

\section{ASTER}

Aster

*alpinus-Rock Aster....... . 25

novae-angliae-New England

Aster. 


\section{NAMED HARDY ASTERS}

Climax-Light lavender-blue.. $\$ \$ .30 \quad \$ 2.40$

Pink Perfection.......... . $30 \quad 2.40$

\begin{tabular}{|c|c|c|}
\hline ASTILBE & & \\
\hline Gloria-Deep pink. & .40 & 3.50 \\
\hline Moerheim-Pure White. . & .50 & 4.00 \\
\hline Salland-Red. & .50 & 4.00 \\
\hline
\end{tabular}

\section{BELLIS English Daisy}

perennis-English Daisy..... $.25 \quad 2.20$

\section{BOLTONIA Boltonia}

latisquama-Violet Boltonia. . $\quad .25 \quad 2.20 \quad 15.00$

\section{CAMPANULA Bellflower}

*alliariaefolia - Spurred Bellflower.............. $\quad .40 \quad 3.50$

*carpatica - Carpathian Bellflower............. $\quad .30 \quad 2.40$ medium - Canterbury-Bell (Pink-Blue-White-Mixed)... . m. calycanthema - Cup-andSaucer Bellflower (Pink-BlueWhite-Mixed)........... persicifolia - Peachleaf Bell-

flower............ $\quad .30 \quad 2.40 \quad 18.00$

\section{CENTAUREA}

Centaurea

*montana-Mountain-bluet... . .30

*montana alba-White Mountain-bluet .

CERASTIUM

Cerastium

*tomentosum-Snow-in-summer $\quad .25$

\section{CERATOSTIGMA}

*plumbaginoides - Larpente plumbago............. $\quad .35 \quad 2.70$

\section{CHEIRANTHUS Wallfower}

*allioni-Wallflower.......... $\quad .30 \quad 2.40$

\section{CHRYSANTHEMUM}

(See Pyrethrum)

\section{Chrysanthemum}

*coreanum - Korean Chrysanthemum............ $\quad .30 \quad 2.50$

maximum-Shasta Daisy...... $\quad .25 \quad 2.20$ 


\section{Each Per $10 \quad$ Per 100}

\section{CHRYSANTHEMUMS (Continued)}

\section{NAMED CHRYSANTHEMUMS}

A. Barham-Golden Bronze... $\$ \$ .30 \quad \$ 2.40 \quad \$ 18.00$

Autumn Glow-Large rose

crimson............ $\quad .30 \quad 2.40 \quad 18.00$

Boston-Golden Bronze..... $\quad .30 \quad 2.40 \quad 18.00$

Carrie-Yellow.............. $30 \quad 2.40$

Cranford White-White..... $\quad .30 \quad 2.40$

Cranfordia-Golden Bronze... $\quad .30 \quad 2.40$

Eden-Pink............ $\quad .30 \quad 2.40$

$\begin{array}{llll}\text { Field of Snow-Large White. . } & .30 & 2.40 & 18.00\end{array}$

Garchar's Crimson-Crimson. $\quad .30 \quad 2.40$

Golden Pheasant-Orange Yel-

low.............. . $30 \quad 2.40 \quad 18.00$

Indian-Bright Indian red-

Aster type............. $\quad .30 \quad 2.40 \quad 18.00$

Lillian Doty-Soft pink..... $\quad .30 \quad 2.40$

Little Bob-Bronze Button ... $\quad .30 \quad 2.40 \quad 18.00$

Marie Antoinette-Large deep

pink............. $.30 \quad 2.40 \quad 18.00$

Old Homestead-Large pink. $\quad .30 \quad 2.40$

Skibo-Yellow button...... $\quad .30 \quad 2.40 \quad 18.00$

CONVALLARIA Lily of the Valley

majalis-Clumps.......... .50 $\quad 4.50 \quad 40.00$

majalis-Strong Pips........ $\quad .15 \quad 1.00 \quad 7.50$

COREOPSIS Coreopsis

grandiflora-Big Coreopsis.... $\quad .25 \quad 2.20 \quad 15.00$

lanceolata-Lance Coreopsis.. $\quad .25 \quad 2.20$

\section{DELPHINIUM Larkspur}

elatum-Bee Larkspur....... $\quad .30 \quad 2.40$

formosum-Belladonna...... $\quad .30 \quad 2.40$

f. Bellamosum-Dark blue form of Belladonna.......... $\quad .30 \quad 2.40$

Blackmore \& Langdon Hybrids $\quad .60 \quad 5.00$

\section{DIANTHUS Pink}

barbatus (Sweet William) (Pink-

Red and White)........ .25 $\quad .20 \quad 15.00$

*caesius............... $\quad .30 \quad 2.40$

*deltoides-Maiden pink..... $\quad .30 \quad 2.40 \quad 18.00$

*d. alba-White Maiden pink. . $\quad .30 \quad 2.40$

plumarius-Grass pink..... $.25 \quad 2.20$

\section{NAMED HARDY PINKS}

*Her Majesty-Large pure white $\quad .30 \quad 2.40$

*Lord Lyons-Pink......... $\quad .30 \quad 2.40$

\section{DICENTRA}

*eximea-Fringed Bleedingheart $\quad .35 \quad 2.70$

spectabilis-Bleedingheart.... $\quad .75 \quad 7.00$




\begin{tabular}{|c|c|c|c|}
\hline & $\begin{array}{r}\text { Each } \\
\text { Gasplant }\end{array}$ & Per 100 & Per 100 \\
\hline fraxinella-Gasplant. & .. $\$ .40$ & $\$ 3.50$ & \\
\hline albus-White Gasplant. . & .40 & 3.50 & \\
\hline DIGITALIS & Foxglove & & \\
\hline ambigua-Yellow Foxglove... & .30 & 2.40 & 18.00 \\
\hline $\begin{array}{l}\text { purpurea-Common Foxglove. } \\
\text { p. alba-Common White Fox- }\end{array}$ & $\begin{array}{l}e . \\
x-\end{array}$ & 2.40 & 18.00 \\
\hline glove $\ldots \ldots \ldots \ldots \ldots \ldots$ & .30 & 2.40 & 18.00 \\
\hline
\end{tabular}

\section{DRABA}

*fladnizensis - Arctic

\section{Whitlowgrass}

Whitlowgrass........... .50

\section{ECHINACEA}

Hedgehog-Coneflower

purpurea-Purple Coneflower . $\quad .30$

ECHINOPS
pumilum-Globethistle

\section{ERYSIUM}

\section{Blistercress}

*pulchellum-Rockery Blister-

cress................ $\quad .30 \quad 2.40$

\section{EUPATORIUM Eupatorium urticaefolium (ageratoides)}

$\begin{array}{lll}\text { Snow Thoroughwort....... } \quad .35 & 2.70\end{array}$

\section{FESTUCA Fescue}

*glauca-Blue Fescue......... $\quad .30 \quad 2.40$

\section{FILIPENDULA Meadowsweet}

*hexapetala (Spiraea filipendula)

-Dropwort............ $\quad .30 \quad 2.40$

*hex. fl. pl.—Double Dropwort. $\quad .30 \quad 2.40$

\section{GAILLARDIA Gaillardia}

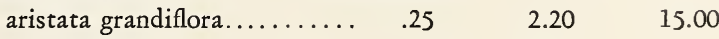

a. maxima................ $.25 \quad 2.20$

\section{GALIUM Bedstraw}

*verum-Yellow Bedstraw.... . .50

\begin{tabular}{lll} 
GEUM & \multicolumn{3}{c}{ Avens } \\
chiloense atrosanguineum - & \\
Double Crimson Geum..... & .30 & 2.40 \\
c. Mrs. Bradshaw........... & .35 & 3.00
\end{tabular}

\section{GYPSOPHILA}

\section{Gypsophila}

Ehrlei-New early dble-flower-

ing white............ 1.50

paniculata-Babysbreath..... $\quad .30$

paniculata fl. pl.-Dble. Babys-

$\begin{array}{llll}\text { breath................. } & .40 & 3.50 & 30.00\end{array}$

$\begin{array}{llll}\text { paniculata fl. pl. Bristol Fairy.. } & .60 & 5.50 & 50.00\end{array}$




\begin{tabular}{|c|c|c|}
\hline $\begin{array}{l}\text { HELENIUM } \\
\text { autumnale-Common }\end{array}$ & $\begin{array}{c}\text { Each } \\
\text { Sneezeweed } \\
\text { Sneeze- }\end{array}$ & Per \\
\hline weed & $\ldots \ldots \ldots . \$ .30$ & $\$ 2.40$ \\
\hline a. Riverton Beauty... & .35 & 2.70 \\
\hline a. Riverton Gem. & .35 & 2.70 \\
\hline hoopesi-Orange Sneez & eweed. & 2.70 \\
\hline
\end{tabular}

\section{HELIANTHUS \\ Sunflower}

decapetalus - Thinleaf Sun-

flower................. $.25 \quad 2.20$

\begin{tabular}{ccc} 
HEMEROCALLIS & \multicolumn{2}{c}{ Daylily } \\
flava-Lemon Day Lily....... & .40 & 3.00 \\
fulva-Tawny Day Lily...... & .25 & 2.20 \\
middendorfi-Amur Day Lily. & .30 & 2.40 \\
thunbergi-Japanese Day Lily. & .30 & 2.40
\end{tabular}

\section{HERNIARIA Burstwort}

*glabra-Burstwort......... $\quad .40 \quad 3.50$

\section{HESPERIS Rocket}

*matronalis-Dames Rocket... $\quad .30$

\section{HEUCHERA Alumroot}

*sanguinea-Coralbells........ . .35

*s. alba-White Coralbells.... . $\quad .30 \quad 2.40$

*hybrids............... $\quad .30 \quad 2.40$

\section{HIBISCUS \\ Rosemallow}

moscheutos - Common Rose-

mallow............... . 30

HOSTA (Funkia) Plantainlily

caerulea-Blue Plantainlily ... $\quad .30 \quad 2.40$

\section{HYPERICUM St. Johnswort}

*repens................ .40 3.50

HYSSOPUS
*officinalis rosea.............. Hyssop

\section{IBERIS}

*gibraltarica-Gibraltar Candytuft.................. $\quad .30 \quad 2.40$

*sempervirens-Evergreen candytuft................... $\quad .30 \quad 2.40$

*s. Little Gem............. $\quad .30 \quad 2.40$ 


\begin{tabular}{|c|c|c|c|}
\hline RMAN-Tall Bearded & Each & Per 10 & Per 100 \\
\hline Florentina Blue............ & $\$ .30$ & $\$ 2.40$ & \\
\hline Her Majesty.............. & .35 & 3.00 & \\
\hline Kochi.................. & .30 & 2.40 & \\
\hline Loreley.................. & .35 & 2.70 & \\
\hline Madame Chereau. ........... & .30 & 2.40 & \\
\hline Pauline .................. & .30 & 2.40 & \\
\hline Perfection... & .35 & 3.00 & \\
\hline Princess Victoria Louise...... & .35 & 2.70 & \\
\hline Rebecca........... & .30 & 2.40 & \\
\hline Rhein Nixe............. & .35 & 3.00 & \\
\hline Mixed $\ldots \ldots \ldots \ldots \ldots \ldots \ldots$ & .30 & 2.40 & 18.00 \\
\hline
\end{tabular}

\section{KAEMPFERI-Japanese}

Alida.................. $.50 \quad 4.00$

Helen von Siebold ......... $\quad .50 \quad 4.00$

Mahogany.............. $\quad .50 \quad 4.00$

Neptune............... $\quad .50 \quad 4.00$

Paragon................ $\quad .50 \quad 4.00$

Purple and Gold .......... $\quad .50 \quad 4.00$

\section{MISCELLANEOUS IRIS}

siberica............. $\quad .30 \quad 2.40$

s. alba............... $.25 \quad 2.20$

\section{KNIPHOFIA}

uvaria grandiflora-Dayglow

Torchlily............. $\quad .30 \quad 2.40$

u. pitzeriana-Bonfire Torchlily.................. $\quad .30 \quad 2.40$ rucki-Tuck Torchlily...... $\quad .30 \quad 2.40$

\section{LATHYRUS Pea \\ latifolius-Perennial Pea..... $\quad .30 \quad 2.40$}

LAVANDULA

Lavender

officinalis (vera) True lavender. $\quad .35$

ILATRIS

pycnostachya - Cattail Gay-

feather............. $\quad .30 \quad 2.40$

\section{LILIUM}

Lily

auratum-Goldband Lily..... $\quad .50$

candidum-Madonna Lily... . $\quad .40$

elegans-Deep maroon ...... . . 35

hansoni-Hanson Lily....... . .75

henryi-Henry Lily......... $\quad .75$

regale-Royal Lily

$.60 \quad 5.50$

speciosum album-White Spe- 


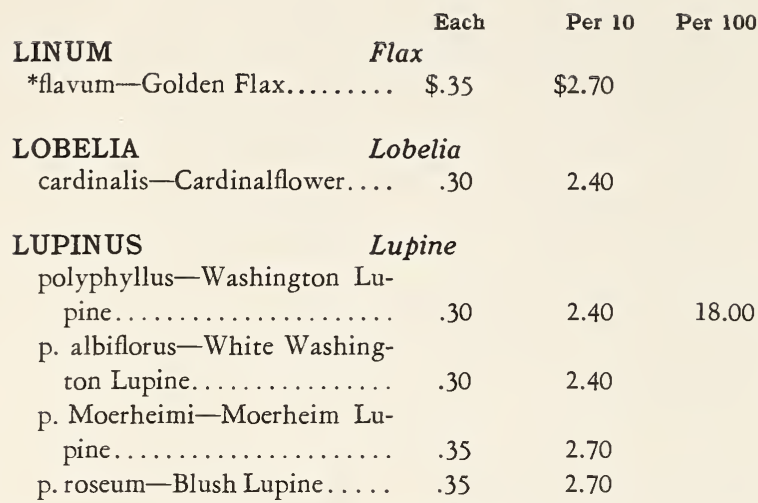

\section{LYCHNIS Campion}

chalcedonica............. $\quad .30 \quad 2.40$

coronaria-Rose Campion.... $\quad .25 \quad 2.20$

c. alba-White Campion...... $\quad .25 \quad 2.20$

viscaria splendens-Rosepink

Campion............... $\quad .30 \quad 2.40$

viscaria splendens fl. pl.-Dble.

Rosepink Campion........ $\quad .30 \quad 2.40$

LYSIMACHIA Loosestrife

nummularia-Moneywort... $\quad .25 \quad 2.20$

LYTHRUM

salicaria roseum-Rose Loose-

strife................ $30 \quad 2.40$

MALVA Mallow

alcea-Hollyhock Mallow.... $\quad .30 \quad 2.40$

\section{MENTHA Mint}

piperita-Peppermint........ $\quad .25 \quad 2.20$

spicata-Spearmint......... $\quad .30 \quad 2.40$

\section{MERTENSIA Bluebells}

$\begin{array}{lll}* \text { virginica-Virginia Bluebells. . } \quad .30 & 2.40\end{array}$

\section{MONARDA Beebalm}

didyma-Oswego Beebalm... $\quad .30 \quad 2.40$

\section{OENOTHERA}

Evening-Primrose or Sundrops

glauca fraseri-Fraser Sundrops $\quad .30 \quad 2.40$

*missouriensis-Ozart Sundrops $\quad .40 \quad 3.00$

speciosa.................... $.35 \quad 2.70$

\section{PACHYSANDRA Japanese Pachysandra}

$\begin{array}{llll}* \text { terminalis-Field-grown...... } & .35 & 2.50 & 18.00\end{array}$ 


$\begin{array}{lccc} & \text { Each } & \text { Per } 10 & \text { Per } 100 \\ \text { PAEONIES } & & \\ \begin{array}{r}\text { Edulis Superba-Early soft pink } \\ \text { Felix Crousse-Medium bright }\end{array} & \$ .75 & \$ 6.00 & \\ \text { red.................... } & 1.00 & 9.00 & \\ \begin{array}{r}\text { Festiva Maxima-Early white } \\ \text { with crimson markings..... }\end{array} & .75 & 6.50 & 50.00 \\ \text { Francois Ortegat-Semi-double } \\ \text { purplish crimson.......... }\end{array}$

\section{PENTSTEMON}

laevigatus digitalis-Foxglove

Pentstemon.......... $\quad .30 \quad 2.40$

\section{PHALARIS}

arundinacea variegata-Ribbon

Grass................. $\quad .30 \quad 2.40$

\section{PHLOX}

\section{PHLOX}

Phlox

divaricata-Blue Phlox...... $\quad .40 \quad 3.00$

paniculata

Garden Phlox

Annie Cook-Flesh pink ..... $\quad .30$

Atlas-Salmon pink......... $\quad .30$

$2.40 \quad 18.00$

B. Comte-Dark red ....... $\quad .30 \quad 2.40 \quad 18.00$

$\begin{array}{lll}\text { Baur's Pink-Bright pink.... } & .30 & 2.40 \quad 18.00\end{array}$

Blue Hill-Nearest to a blue Phlox of any we have yet seen.................... $35 \quad 3.00$

Commander-in-Chief-Crimson with dark eye........ $\quad .35 \quad 3.00$

Debs-Bright fiery crimson... $\quad .75 \quad 7.00$

Deutschland-Rich scarlet... $\quad .35 \quad 2.70$

Elizabeth Campbell - Bright salmon pink, dark red eye... $\quad .35 \quad 3.00$ 


\section{PHLOX (Continued)}

Enchantress............ \$.35

Independence-Pure White.... .30

Jules Sandeau-Large, fine, free flowering, pure pink... Julius Heurlin-Salmon pink. .

Lord Raleigh.............

Maid Marion-Soft lavender. .

Mme. P. Langier-Bright red with vermilion center .....

Mrs. Jenkins-Pure white, very

large truss.............

Percheau d'Island-Tall with deep red blossoms..........

R. B. Struthers-Bright pinkish salmon-crimson eye....

Rijnstroom - Bright carmine rose...................

Sièoldi-Crimson.........

Special French-Glowing pink

Victor-Bright salmon pink..

suff ruticosa-Indian Chief.... .

s.-Miss Lingard. . . . . . . . . . .

*subulata-Moss pink........ .25

*s. alba-White Moss pink.... $\quad .25$

*s. G. F. Wilson-Blue Moss... $\quad .25$

\section{Groundcherry}

.30

2.40

\section{PLATYCODON}

grandiflora-Balloonflower . .

Balloonflower

.30

\section{POLEMONIUM}

*caeruleum-Greek-valerian. . .

${ }^{*}$ c. album-White Greek-valerian................ 30

\section{POTENTILLA}

*atrosanguinea - Himalayan

Cinquefoil............ .30

*hybrida Miss Willmott...... . .35

\section{PRIMULA}

Primrose

*acaulis-English Primrose... . .35

*beesiana ............... .35

elatior alba-Oxlip Primrose. . .35

japonica-Japanese Primrose. . $\quad 30$

*veris-Cowslip Primrose (upright)........... 30 


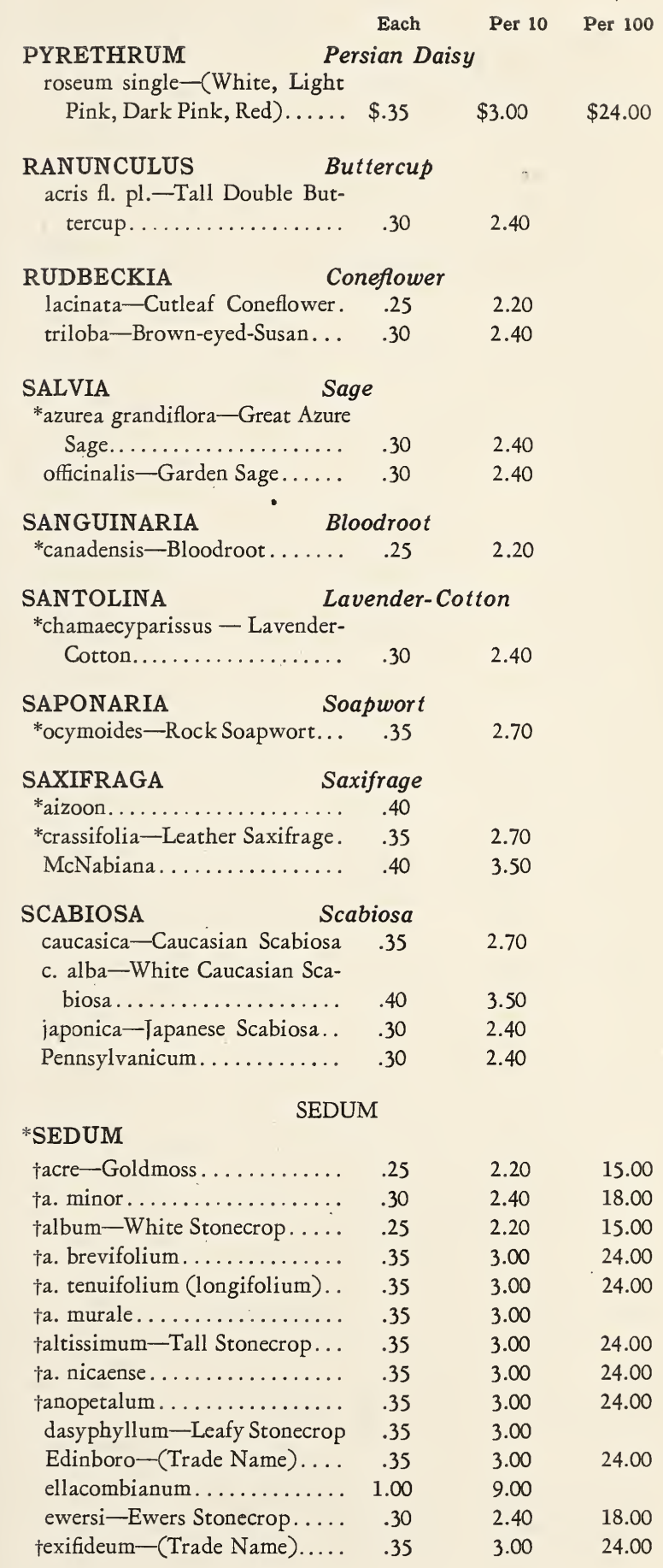




\begin{tabular}{|c|c|c|c|}
\hline SEDUM (Continued) & Each & Per 10 & Per 100 \\
\hline hispanicum-perennial variety & $\$ .30$ & $\$ 2.40$ & \\
\hline hybridum-Hybrid Stonecrop. & 1.00 & 9.00 & \\
\hline ibericum................ & 1.75 & & \\
\hline kamtschaticum-Orange Stone- & & & \\
\hline crop $\ldots \ldots \ldots \ldots \ldots \ldots$ & .30 & $\begin{array}{l}2.40 \\
2.50\end{array}$ & 18.00 \\
\hline lydium-Lydian Stonecrop.... & .30 & 2.50 & 20.00 \\
\hline maximowiczi-Amur Stonecrop & .30 & 2.40 & 18.00 \\
\hline maximum-Great Stonecrop.. & .30 & 2.40 & 18.00 \\
\hline oreganum................ & .50 & 4.50 & 40.00 \\
\hline reflexum-Jenny Stonecrop.... & .30 & 2.50 & 20.00 \\
\hline rupestre-Cliff Stonecrop...... & .30 & 2.40 & \\
\hline $\begin{array}{l}\text { r. minus................. } \\
\text { sarmentosum-Stringy Stone- }\end{array}$ & .35 & 3.00 & 24.00 \\
\hline crop...................... & .30 & 2.40 & 18.00 \\
\hline sexanglare-Hexagone Stone- & - & & \\
\hline crop $\ldots \ldots \ldots \ldots \ldots \ldots \ldots$ & .30 & 2.40 & 18.00 \\
\hline sieboldi-Siebold Stonecrop. . . & .35 & 3.00 & \\
\hline spectabile-Showy Stonecrop. & .25 & 2.20 & 15.00 \\
\hline $\begin{array}{l}\text { s. Brilliant................ } \\
\text { s.variegata-Variegated Showy }\end{array}$ & .30 & 2.50 & 20.00 \\
\hline Stonecrop................ & .30 & 2.40 & 18.00 \\
\hline 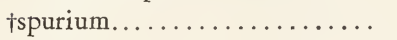 & .25 & 2.20 & 15.00 \\
\hline †s. album................ & 2.50 & 22.50 & \\
\hline †s. oppositifolium............ & 1.75 & & \\
\hline $\begin{array}{l}\text { †s. splendens. . . . . . . . . . . . } \\
\text { †stoloniferum }- \text { True Running }\end{array}$ & 3.00 & 25.00 & \\
\hline Stonecrop.............. & .30 & 2.40 & 20.00 \\
\hline ternatum-Mountain Stonecrop & .30 & 2.40 & \\
\hline t. minus. . . . . . . . . . . & .30 & 2.40 & 20.00 \\
\hline †undulatum............... & 1.50 & 12.00 & \\
\hline †wallichianum. . & 4.00 & 35.00 & \\
\hline W. M. Pascoe . ............. & 1.00 & 9.00 & \\
\hline
\end{tabular}

\section{SEMPERVIVUM Houseleek}

*alberti................. .25 2.20

*arachnoideum - Spiderweb

Houseleek.............. . . $25 \quad 2.20$

*globiferum-Globe Houseleek $\quad .25 \quad 2.20$

*soboliferum-Hen and chickens $\quad .25 \quad 2.20$

*tectorum-Roof Houseleek.... $\quad .25 \quad 2.20$

\section{SIDALCEA Prairiemallow}

Rosy Gem............. $\quad .30 \quad 2.40$

\section{TEUCRIUM Germander}

*orientale............... .50 4.00

\section{THALICTRUM Meadowrue}

aquilegifolium - Columbine

Meadowrue........... $\quad .30 \quad 2.40$ 


\begin{tabular}{|c|c|c|}
\hline 1 & Each & Per 10 \\
\hline THYMUS & Thyme & \\
\hline *aureum. & . $\$ .35$ & $\$ 3.00$ \\
\hline \multicolumn{3}{|c|}{ *serpyllum coccineum-Crimson } \\
\hline Thyme................. & .35 & 2.70 \\
\hline *s. lanuginosus-Woolly Thyme & .30 & 2.40 \\
\hline
\end{tabular}

\section{TRADESCANTIA Spiderwort}

$\begin{array}{lll}\text { virginiana-Virginia Spiderwort } \quad .30 & 2.40\end{array}$

\section{TROLLIUS Globeflower}

asiaticus-Siberian Globeflower $\quad .50 \quad 4.00$

europaeus - Common Globe-

flower................ $.40 \quad 3.50$

Dwyer's Giant........... $\quad .50 \quad 4.00$

\section{VALERIANA Valerian}

officinalis-Garden Heliotrope $\quad .30 \quad 2.40$

VERBENA Verbena

hastata-Blue Vervain...... $\quad .30 \quad 2.40$

\begin{tabular}{ccc} 
VERONICA & \multicolumn{3}{c}{ Speedwell } \\
*allioni-Allioni Speedwell .... & .35 & 3.00 \\
longifolia subsessilis-Clump & & \\
Speedwell................. & .40 & 3.50 \\
longifolia subsessilis-Blue Jay & .40 & 3.50 \\
*repens-Creeping Speedwell... & .35 & 2.70 \\
spicata-Spike Speedwell..... & .30 & 2.40
\end{tabular}

\section{VINCA Periwinkle}

$\begin{array}{llll}\text { minor-Common Periwinkle. } & .25 & 2.00 & 15.00\end{array}$

VIOLA . Violet

*cornuta-Tufted Pansy...... $\quad .30 \quad 2.40$

*c. alba (type) White Tufted Pansy.................. $\quad .30 \quad 2.40$

*Jersey Gem............... $\quad .35 \quad 3.00$

*Hybrids-Tufted Pansies;Admiration, Lutea, Mauve Queen, Purple Queen, White Perfection................. $.25 \quad 2.20$

odorata-Single Russian-Sweet Violet............... $\quad .30 \quad 2.40$

\section{YUCCA}

\section{Yucca}

filamentosa-Common Yucca:

\begin{tabular}{|c|c|c|}
\hline $2 \mathrm{yrs}$ & .30 & 2.40 \\
\hline yrs.................. & .35 & 3.00 \\
\hline yrs............... & .40 & 3.50 \\
\hline
\end{tabular}




\section{Hardy Roses}

Each Per 10 Per 100

Strong Field-Grown Plants, 2 yrs. $\$ 1.00 \quad \$ 9.00$

\section{HYBRID PERPETUAL ROSES}

RED

American Beauty-Crimson

Baron de Bonstettin-Velvety maroon; large and full

General Jacqueminot-Bright scarlet crimson

Hugh Dickson-Brilliant crimson, shaded with scarlet

M. P. Wilder-Cherry carmine

Prince Camille de Rohan-Dark red

Ulrich Brunner-Brilliant cherry-red

\section{PINK}

Anne de Diesbach-Large double carmine

Clio-Large flesh color; rosy pink center

George Arends-Large fragrant pink

John Hopper-Bright rose, carmine center

Mme. Gabriel Luizet-Light silvery pink

Magna Charta-Pink and carmine

Mrs. John Laing-Large soft pink; fragrant and steady bloomer

Paul Neyron-Deep rose; very large

\section{WHITE}

Frau Karl Druschki (Snow Queen)-Pure white

Mme. Plantier-Pure white

Margaret Dickson-White with pale flesh center; large

\section{YELLOW}

Harison's Yellow-Bright yellow-semi-double

Persian Yellow-Deep yellow

Soliel d'Or-Orange gold

\section{HYBRID TEA ROSES}

\section{RED}

Edward Mawley-Velvety crimson

Etoile de France-Large double velvety crimson; center ruby red

General MacArthur-Large velvety scarlet

George Dickson-Velvety black crimson

Gruss an Teplitz-Scarlet, shading to velvety crimson

Red Premier-Bright carmine

Red Radiance-Deep red

Templar-Crimson red

\section{PINK}

Betty-Large coppery rose, shaded with yellow

Briarcliff-Rose pink

Dean Hole-Silvery carmine, shaded salmon 


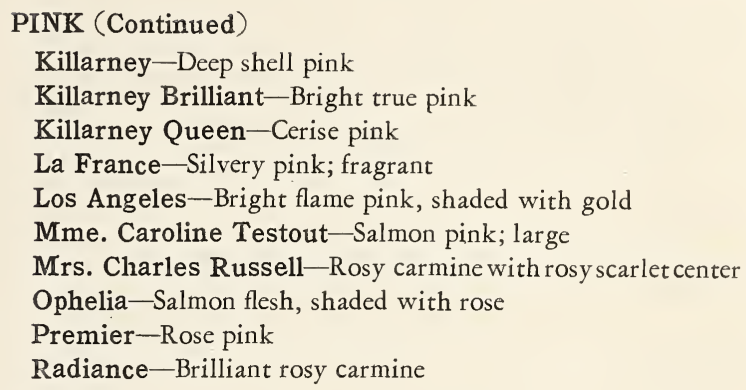

\section{WHITE}

Bessie Brown-Large double flowers, almost pure white

Killarney White-Pure white; long pointed buds

\section{YELLOW.}

Lady Hillingdon-Deep apricot yellow Mrs. Calvin Coolidge-Golden yellow

Sunburst - Rich yellow, shaded coppery orange

\section{TALISMAN}

$\$ 2.50$ each

A beautiful new Rose. Large orange-saffron

\section{POLYANTHA ROSES}

$\$ 1.00$ each; $\$ 9.00$ per 10

Baby Rambler-Red, extremely free blooming

Jessie-Huge clusters of bright cherry crimson flowers. Do not fade.

\section{CLIMBING ROSES}

75c. each; $\$ 6.00$ per 10

(Unless noted)

Varieties marked with an asterisk $\left(^{*}\right)$ can be furnished also in large plants for $\$ 1.25$ each.

\section{RED}

Climbing American Beauty-Large crimson flowers

Crimson Rambler-Immense clusters of double crimson flowers

Excelsa-Double crimson flowers; good foliage

Hiawatha-Single deep crimson, clear white at base of petals

Paul's Scarlet Climber-Vivid scarlet

\section{PINK}

American Pillar-Single rosy pink

Dr. Van Fleet-Deep flesh pink

Dorothy Perkins-Shell Pink 


\title{
PINK (Continued)
}

Mary Wallace-Semi-double; bright clear rose pink, $\$ 1.00$ each; $\$ 9.00$ per 10

Tausendschon-Large trusses of pink flowers

\section{WHITE}

Silver Moon-Semi-double; pure white flowers

*White Dorothy Perkins-Double pure white flowers

\section{YELLOW}

Gardenia-Buds bright yellow, flowers cream. Very hardy.

\section{ROSA RUGOSA HYBRIDS}

$\$ 1.00$ each; $\$ 9.00$ per 10

Hansa-Red

Sir Thomas Lipton-White

\section{Fruit Trees}

\section{STANDARD APPLES}

Each Per $10 \quad$ Per 100

2 yrs., 5 to $7 \mathrm{ft} \ldots \ldots \ldots \ldots \$ 1.00 \quad \$ 9.00$

\author{
Summer Varieties \\ Red Astrachan \\ Yellow Transparent

Autumn Varieties
Gravenstein
Wealthy
Winter Varieties
Baldwin
Delicious
McIntosh Red
Rhode Island Greening
Roxbury Russet
Tolman Sweet

\section{CRAB APPLES}

2 yrs., 5 to $7 \mathrm{ft} \ldots \ldots \ldots . .1 .00 \quad 9.00$

Hyslop

\section{STANDARD PEARS}

2 yrs., 5 to $7 \mathrm{ft} \ldots \ldots \ldots \ldots . .1 .50 \quad 12.50$

\section{Summer Varieties}

Bartlett

Clapp's Favorite

\section{Autumn Varieties}

Beurre Bosc

Seckel

Sheldon 


$\begin{array}{llll}\text { CHERRIES } & \text { Each } & \text { Per } 10 & \text { Per } 100 \\ 2 \text { yrs., } 5 \text { to } 7 \mathrm{ft} . \ldots \ldots \ldots \ldots & \$ 1.50 & \$ 14.00 & \end{array}$

Sweet

Black Tartarian

Gov. Wood

Tart

Early Richmond

Montmorency

\section{PEACHES}

4 to $5 \mathrm{ft} . \ldots \ldots \ldots \ldots \ldots \ldots$

Crawford's Early

Crawford's Late ,

Elberta

Rochester

Stump

\section{PLUMS}

2 yrs., 5 to $7 \mathrm{ft} . \ldots \ldots \ldots \ldots \quad 1.50 \quad 14.00$

\section{Japanese}

Abundance

Burbank

Damson

\section{European}

Bradshaw

Lombard

\section{QUINCES}

4 to $5 \mathrm{ft} . \ldots \ldots \ldots \ldots \ldots \ldots \quad 1.25 \quad 11.00$

Champion

Orange

\section{Small Fruits}

\section{ASPAR AGUS}

2 yr. roots

Conover's Colossal.........

Giant Argenteuil.........

Martha Washington.......

Palmetto...............

.40

$.60 \quad 4.00$

$.40 \quad 3.00$

\section{BLACKBERRIES}

Erie

Eldorado

Snyder

\section{BLACK CAPS}

\section{Gregg}


GRAPES

Each

Per 10

Per 100

2 yrs. (Unless noted)....... $\$ .60 \quad \$ 5.00$

\author{
Blue-Black \\ Concord \\ Campbell's Early \\ Worden
}

Red

Brighton

Delaware

Salem

\title{
White
}

Green Mountain......... $\quad .75$

Moore's Diamond

Niagara

\section{RASPBERRIES}

Columbian

Cuthbert

Golden Queen

Herbert

St. Regis

\section{RHUBARB}

Linnaeus

\section{Bulbs}

\section{GLADIOLUS}

Each Per doz. Per 100

Albania-Fine new white-

$\begin{aligned} & \text { large......................... } \\ & \text { Alice Tiplady-Saffron Orange }\end{aligned}$

America-Soft lavender pink

Crackerjack-Red with cream throat............ .05

Crimson Glow-Scarlet.....

E. J. Shaylor-Ruffled rosepink.............

Halley-Delicate salmon pink

Herada-Pure mauve........

Le MarechalFoch-Pale pink

Longfellow-La France pink..

MaryPickford-Creamy white

Mrs.Dr.Norton-Delicatepink

Mrs. F. C. Peters-Best late lavender...............

Mrs.Leon Douglas-Begonia rose................. .10 


\section{GLADIOLAS (Continued)}

\begin{tabular}{|c|c|c|c|}
\hline Peace-Late white & $\$ .07$ & $\$ .75$ & $\$ 4.75$ \\
\hline Prince of India-Smoky color & .25 & 2.50 & \\
\hline Principine & .07 & .75 & \\
\hline Rose Ash-Dusky rose & .10 & 1.00 & \\
\hline Schwaben-Soft yellow....... & .05 & .50 & 3.50 \\
\hline Sirius-Salmon pink : & .05 & .50 & 3.50 \\
\hline The Pearl-Rose pink. & .05 & .50 & \\
\hline $\begin{array}{l}\text { Wilbrink-Pink with soft yel- } \\
\text { low blotch................ }\end{array}$ & .05 & 50 & \\
\hline Mixed. & .05 & .50 & \\
\hline
\end{tabular}

In order to accommodate our customers with DUTCH BULBS for Fall Planting, we will have this Autumn:

Tulips, Hyacinths, Crocus, Chionodoxa, Frittillaria, Muscari and Scilla Bulbs in variety.

We will be very glad to send a complete list upon request.

\section{Garden and Greenbouse Plants}

We will have the following plants to offer, price to de pend upon the size of pot and plant.

\section{AGERATUM}

Blue-Dwarf

Blue Perfection

\section{ASPIDISTRA}

lurida variegata-Striped Aspidistra

\section{ASTER}

\section{Ostrich Plume}

Lavender

Purple

Rose pink

Shell Pink

White

\section{ANTHERICUM mandaeanum}

\section{BEGONIAS}

\section{CACTUS}

\section{CALENDULAS}

Lemon Queen

Orange King

\section{CANNAS}

\section{Green Foliage}

Beaute Poitevine-Deep crimson. $31 / 2 \mathrm{ft}$.

Eureka-White. $4 \mathrm{ft}$.

Express-Deep crimson. $\quad 31 / 2 \mathrm{ft}$.

Gladiator-Yellow, dotted red. $5 \mathrm{ft}$.

Mme. Berat-Rose pink. $4 \mathrm{ft}$. 


\section{CANNAS (Continued)}

Mme. Crozy-Vermilion scarlet, with narrow golden border. $3 \frac{1}{2} \mathrm{ft}$.

Mrs. Alfred Conard-Salmon pink. $3 \frac{1}{2} \mathrm{ft}$.

Pennsylvania-Scarlet overlaid with orange. $6 \mathrm{ft}$.

President-Crimson. $4 \mathrm{ft}$.

Richard Wallace-Canary yellow. $4 \mathrm{ft}$.

\section{Bronze Foliage}

King Humbert-Orange-scarlet. $4 \mathrm{ft}$.

\section{CLARKIA}

Orange King

\section{COLEUS}

\section{COREOPSIS}

drummondi (Golden Wave)

Fire King

\section{COSMOS}

Pink

Crimson

White

\section{CRASSULA}

\section{DIMORPHOTHECA aurantiaca (Cape-Marigold)}

\section{DRACENAS}

indivisia

\section{ECHERVERIA}

\section{FICUS ELASTICA-Rubber plant}

\section{GERANIUMS}

Alphonse Ricard-Semi-double, bright vermilion scarlet Beaute Poitevine--Double salmon pink

Michael Buchner-White

Radio Red-Scarlet

S. A. Nutt-Crimson, semi-double

\section{IVY-LEAVED GERANIUMS \\ Pink \\ From Pots \\ Hanging Baskets}

\section{HELIOTROPE}

Lavender

\section{HYDRANGEAS}

French

\section{IBERIS-Candytuft}

Carmine

Dobbie's White Spirale 
IMPATIENS

holsti

IPOMOEA hederacea-Ivyleaf Morning-Glory

LANTANA

Dwarf hybrids

\section{LOBELIA}

Blue Wings

MARIGOLDS

Dwarf French

MYRTUS-Myrtle

communis

\section{PETUNIAS}

Double mixed

Dwarf rose

Rosy Morn

PELARGONIUMS-Lady Washington Geraniums

Pink with crimson blotch

White with crimson blotch

Springtime

\section{SALPIGLOSSIS}

Light blue and gold

Scarlet

\section{SALVIAS-Scarlet Sage splendens Bonfire}

SCHIZANTHUS-Butterflyflower

wisetonensis

\section{SNAPDRAGON}

Crimson

Pink

Yellow

White

\section{VERBENAS}

Pink

Scarlet

White

\section{VINCA-Periwinkle}

\section{WANDERING JEW}

\section{ZINNIAS}

Giant double

Golden yellow

Bright rose

Carmine

White 


\section{Window Boxes}

Water-tight, galvanized steel box, finished in dark green enamel, $8 \frac{1}{2}$ inches wide, $61 / 4$ inches deep. Self-watering.

24 inches

30 inches

36 inches
$\$ 1.75$ each

2.25 each

3.00 each

\section{Plant Tubs}

Strongly made Cedar Tubs, bound with electric-welded wire. Made of selected White Cedar and painted green. No handles.

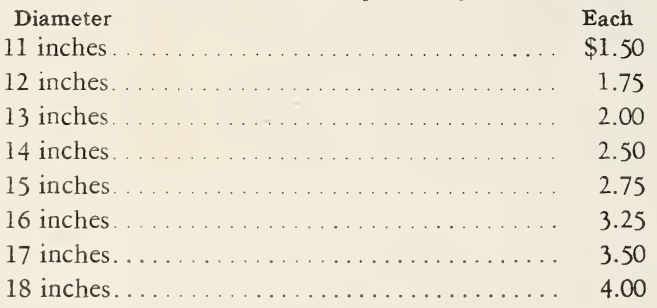

\section{Dutch Peat}

We recommend the use of Dutch Peat for both Fine and Broadleaved Evergreens.

Per bale.

$\$ 4.00$

\section{Grass Seed}

The Grass Seed we use is $96 \%$ pure and in our opinion is the best Grass Seed that can be procured for this section of the country.

Per Pound .............................. $\$ 1.00$

10 Pounds ......................... 7.50

BONE MEAL

\section{Fertilizers}

100 Lbs.

GARDEN FERTILIZER-4-8-4

100 Lbs.

$\$ 3.00$

TANKAGE

100 Lbs. .

\section{UNLEACHED HARDWOOD ASHES}

One of the best Lawn rejuvenators

50 Lbs.

100 Lbs................................... 3.00

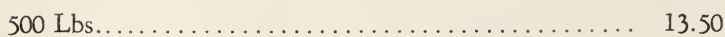

Ton................................... 50.00

\section{VIGORO}

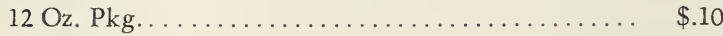

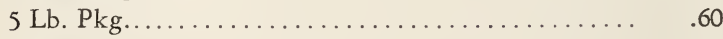

25 Lbs................................ 2.00

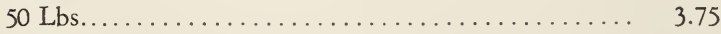

100 Lbs.............................. $\quad 6.00$ 


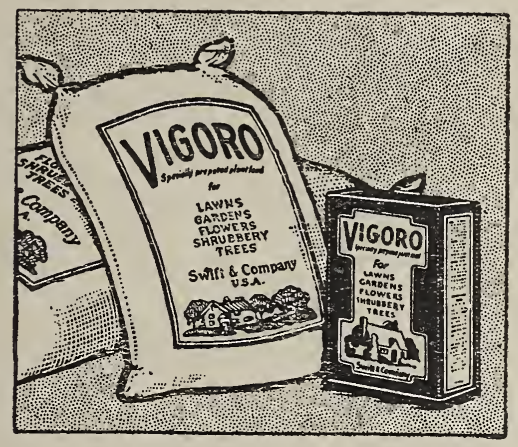

968

\section{Practical Garden Books for the Amateur}

We can supply any Horticultural Book in print. A few which will prove valuable to the home gardener are listed below:

GARDEN Guide. A complete handbook for the amateur gardener. Postpaid: Paper \$1.10; Cloth \$1.65.

1001 Garden Questions Answered. Prof. Alfred C. Hottes. Postpaid: Paper $\$ 1.65$; Cloth $\$ 2.15$.

Foundation Planting. Leonard H. Johnson. Postpaid: Cloth $\$ 3.65$.

Practical Landscape Gardening. Robert B. Cridland. Postpaid: Cloth $\$ 2.65$.

Bulbs That Bloom in the Spring. T. A. Weston. Postpaid: Paper \$1.65; Cloth $\$ 2.15$.

The Complete Home Landscape. Arthur J. Jennings and Leonard H. Johnson. Postpaid: Cloth \$2.65.

American Rock Gardens. Stephen F. Hamblin. Postpaid: Cloth $\$ 1.40$.

Rock Gardens. F. F. Rockwell. Postpaid: Cloth $\$ 1.15$.

These books are splendidly illustrated, well printed and well bound.

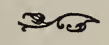



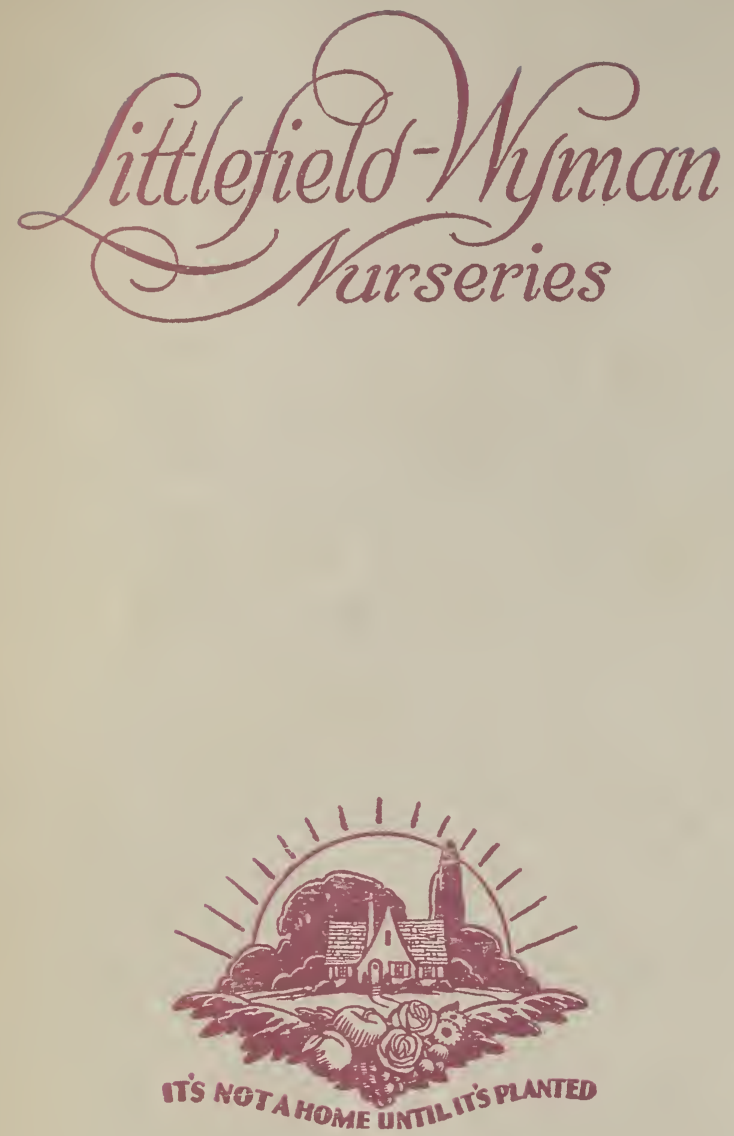